\title{
Are Italians Getting Multidimensionally Poorer? Evidence on the Lack of Equitable and Sustainable Well-Being
}

\author{
Dalila De Rosa' ${ }^{10}$
}

Received: 4 September 2020 / Accepted: 8 June 2021 / Published online: 26 June 2021

(c) Società Italiana di Economia (Italian Economic Association) 2021

\begin{abstract}
According to official statistics, the incidence of absolute poverty in Italy has sharply risen from 3.6 in 2005 to 7.7 percent in 2020, and this number is likely to rise in the post-pandemic period. However, standard poverty measures only consider the monetary aspect of poverty, neglecting the multidimensional nature of the phenomenon. The last decades have offered solid empirical evidence to guide political efforts to tackle both multidimensional wellbeing and poverty. In these times of rising inequalities, these efforts seem particularly valuable for identifying the most vulnerable groups. While Italy has made significant progress in defining multidimensional wellbeing, less attention has been given to multidimensional poverty. Hence, the goal of this paper is to offer a means for measuring multidimensional poverty (MPI) in Italy based on the Alkire-Foster method by using a widely recognized national framework for wellbeing (BES equitable and sustainable wellbeing) as the normative basis for the construction of the index. The contribution of the paper is twofold: (1) on the theoretical side, it seeks to increase the usability of national and international frameworks for wellbeing by proposing a national assessment scheme as a normative base for defining the dimensions of poverty; (2) on the empirical side, it provides evidence on the frequency and composition of multidimensional poverty in Italian regions. The results show that multidimensional poverty in Italy has increased over time, with the percentage of individuals considered as multidimensionally poor rising from 9.5 percent in 2005 to 17.5 percent in 2015 . Moreover, a dimensional breakdown across regions and logistic regression shows that being older, female, from the South and married or widowed increases the probability of facing multidimensional poverty.
\end{abstract}

Keywords MPI (multidimensional poverty index) $\cdot$ BES (equitable and sustainable wellbeing) $\cdot$ Capability approach $\cdot$ Alkire Foster method $\cdot$ Monetary poverty

JEL Classification D63 $\cdot \mathrm{I} 32 \cdot \mathrm{C} 10$

Dalila De Rosa

dalila.derosa@mef.gov.it; dal.derosa@gmail.com

1 Department of Finance, Ministry of Economic and Finance, Rome, Italy 


\section{Introduction}

Due to the recent economic crisis, monetary poverty has sharply increased in almost all developed countries, with the incidence of absolute poverty in Italy rising from 3.6 in 2005 to 7.7 per cent in 2020, at household level. However, standard poverty measures consider only the monetary aspect of poverty while neglecting the multidimensional nature of the phenomenon, which is of growing relevance in this ongoing pandemic. Indeed, people experiencing multiple deprivations before the pandemic are now facing additional COVID-19 risk factors: such is the case of housing deprivation and overcrowding, which hinders effective quarantine (WHO 2020a, b), or pollution, which contributes to respiratory diseases (WHO 2018), or school closures, which amplifies education inequalities (Coe et al. 2020). Even though the last decades have seen advances towards implementing a multidimensional perspective on poverty, this is especially crucial for shaping post pandemic policies, identifying overlapping deprivations and prioritizing the most vulnerable groups (Tavares and Betti 2021; Alkire et al. 2020).

In the vein of multidimensionality, since 2009, the Stiglitz-Sen-Fitousse Commission has contributed to the debate on Beyond GDP not only in academia, but also in official statistics offices and among policy makers, promoting numerous national and international frameworks aimed at measuring human development and spreading the use of composite indices of wellbeing (Bandura 2008). Similarly, as relates to poverty, eminent authors have affirmed the existence of significant mismatches between monetary poverty and multiple deprivations, confirming the need to consider numerous aspects of poverty for human development (Atkinson 2017). However, most of the literature on multidimensional wellbeing and poverty questions whether it is possible to choose the dimensions of wellbeing without the meaningful participation of those at stake. This 'curse' of having to define wellbeing dimensions and the most suitable normative framework picturing a worthwhile life remains a relevant issue in the study of this phenomena (Alkire 2007; Burchi et al. 2014, 2020).

In Italy, considerable effort was made to launch the Equitable and Sustainable wellbeing (BES) as the official framework for measuring wellbeing (see ISTAT 2019). Some indicators of that framework are also included for the evaluation of fiscal policies by the Ministry of Economy and Finance (see Ministero dell'Economia e delle Finanze, 2018), and recently the European Commission has funded a project on the use of wellbeing frameworks for policy (Bacchini et al. 2019, 2020). By contrast, Italy has made little effort for the measurement of multidimensional poverty. Official statistics include four indicators ${ }^{1}$ of poverty within the economic sphere of the BES framework, yet even though these indicators go beyond a purely monetary evaluation of poverty, they do not accommodate a broader multidimensional perspective. Moreover, very few empirical studies have analyzed multidimensional poverty in Italy at a sub-national level (Coromaldi and Zoli 2012; Betti et al. 2008; Giuliano et al. 2012).

1 These are: risk of poverty rate; absolute poverty; material deprivation and very-low work intensity. 
Therefore, the paper aims at filling these gaps by offering a national measure of multidimensional poverty (MPI), employing the National framework for wellbeing (BES) as the normative basis for the construction of the index. The contribution of the paper is twofold: (1) on the theoretical side, it supports the usability of national or international frameworks for wellbeing by proposing them as a normative scheme for the definition of the dimensions of poverty. Considering poverty as a lack of wellbeing, this work is an attempt to offer a solution to the problem of dimensionality by proposing a method that analyses multidimensional poverty within the numerous frameworks for wellbeing of recent creation; (2) on the empirical side, it provides evidence on the level and the composition of multidimensional poverty in Italian regions. The paper does not claim to offer a singular, precise multidimensional poverty measure for Italy, but it provides both an attempt to use a widely-recognized national wellbeing framework to measure poverty and updated evidence on multidimensional poverty in a country where such information is currently scarce.

The following section discusses the role and the evolution of academic and policy efforts to measure multidimensional poverty; Sect. 3 presents the Alkire-Foster method; Sect. 4 discusses the normative as well as the empirical methods applied; Sect. 5 reports the main findings; and Sect. 6 offers final remarks.

\section{On the Role and the Evolution of Multidimensional Poverty Measurement}

Since the beginning of the century, the debate on Beyond GDP has stimulated growing academic interest, as well as greater policy efforts, to identify the limits of GDP as the primary measure of progress and to develop new measurement frameworks (Stiglitz et al. 2009; Fitoussi and Durand 2018). The discussion has broadened the perspective on human development by offering new dashboards of indicators and composite indexes aimed at addressing wellbeing from different life dimensions ${ }^{2}$ (see Bandura 2008 for a full review). In the same vein, "if poverty is understood to be a shortfall from wellbeing” (Alkire et al. 2015 p.4), the necessity of going beyond monetary poverty is clear. In 2015, a high-level Commission led by Sir Anthony Atkinson encouraged national and international institutions to take action to monitor extreme deprivation and to overcome the methodological issues related to nonmonetary measures of poverty (Atkinson et al. 2017).

Many empirical studies have shown the communicative power of multidimensional poverty: Bourguignon (2010) shows that the trends of $\$ 1 /$ day poverty did not match the trends in other Millennium Development Goals (MDGs), concluding that monetary poverty diverges from non-monetary deprivation. Similarly, mismatches between income poverty and multiple deprivations were found in Klasen (2000);

\footnotetext{
2 This is the case of the Millennium Development Goals (MDGs), the Sustainable Development Goals (SDGs), and also the numerous national attempts to create informational frameworks for wellbeing, such as: the Canadian Index of Wellbeing, Measures of Australia's progress, OECD Better life index, and the Italian Equitable and Sustainable Wellbeing, just to mention few.
} 
Alkire and Klasen (2013); Nolan and Whelan (2011); Whelan et al. (2004). Associations across non-monetary deprivations have also shown that multi-dimensional poverty cannot be reduced to one single non-income deprivation alone (Alkire et al. 2015). In addition, the correlation between growth in GDP per capita and improvements in non-income deprivations is very low (Bourguignon et al. 2003, 2006; Drèze and Sen 2013). Hence, multidimensional measures are more suitable for informing public policy on overlapping deprivations and the multiple risk factors so as to permit public authorities to identify the most vulnerable groups.

One of the most critical issues inherent in multidimensional measures is the design of their normative framework, namely the identification of the dimensions/ indicators that capture a worthwhile life. Although is hard to fix ex-ante the borders of wellbeing or ill-being, which should be flexible enough to be adapted to different contexts and specific needs (Alkire 2002; Sen 2004), some selection criteria have been proposed (Alkire 2007) based on: (1) the availability of data; (2) the presence of a widely-accepted definition of the dimensions, such as the Millennium development goals or the Universal Declaration of Human Rights (Burchi et al. 2014, 2020), the Maslow's Pyramid of Needs or the Martha Nussbaum capability list (Nussbaum and Sen 1993); and (3) the presence of a democratic, participatory process to define these criteria in which the civil society is actively involved, as was the case with the Italian BES, discussed in the next section. In the same vein, based on different theoretical underpinnings, several specific approaches to the identification of poverty dimensions have been implemented worldwide (Atkinson et al. 2017).

Within the so called Subjective Approach, based on the idea that the poor are the true experts in poverty and their experiences, priorities, and recommendations have to be taken into account in the definition of poverty, the World Bank has directly conduced participatory studies, asking poor people, in developing countries, to share their ideas of good and bad experiences of life and their definition of wellbeing and ill-being (Narayan 2000a; b). The study resulted in five dimensions of wellbeing, the lack of which gives rise to poverty: material wellbeing, physical wellbeing and security, freedom of choice and action, and good social relations.

By contrast, anchored in the Rawlsian Theory of Justice ${ }^{3}$ and based on the idea that poverty means lack of things that are necessary (Boltvinik 1999), the Unmet Basic Needs approach (UBN) aims to define the set of primary goods necessary to live a good life within the constituent elements of wellbeing (Streeten et al. 1981). It was extensively used, mostly in Latin America, from the beginning of the 1980s (Feres and Mancero 2001) for identifying the proportion of households unable to satisfy one, two, three, or more basic needs in the domains of households condition, access to sanitary services, education and the economic capacity of household members. ${ }^{4}$

In the context of the Amartya Sen Capability theory (CA), poverty is an absolute concept in the space of capabilities (Sen 1983) and the lack of basic capabilities determines misery, which translates observations of starvation, malnutrition and visible

\footnotetext{
${ }^{3}$ For an extended review of this theory see: Rawls (2009). A theory of justice. Harvard University Press.

4 Overcrowding; households with precarious housing; households with no kind of toilet; households with children of school age not attending school; households with four or more dependents per occupied member and whose household head's education was at most second grade of primary education.
} 
hardship into a diagnosis of poverty (Sen 1981, p. 17). In this vein, even though Amartya Sen did not provide a list of capabilities (Sen 2004) many authors have done so (Nussbaum and Sen 1993; Burchi et al. 2014, 2016; Alkire et al. 2011a, b). Among the many attempts to measure poverty within capability theory, the Alkire-Foster class of Multidimensional Poverty Indexes (Global-MPI) assesses poverty over more than one hundred developing countries in relation to education, health and living standards ${ }^{5}$ (Alkire et al. 2015). Only a few National Multidimensional Poverty Indices have been proposed for developed countries, namely Germany (Suppa 2018), Europe (Whelan et al. 2014; Alkire and Apablaza 2016) and the U.S.A. (Glassman 2019).

In Europe, poverty has been linked to the concept of Social Exclusion and defined as the inability to participate in a society (Townsend 1979) due to the lack of the living conditions and amenities which are standard in the societies to which one belongs. In this context, many empirical works (Mack and Lansley 1985; Ringen 1988; Callan et al. 1993; Muffels and Vriens 1991; Whelan et al. 2001; Nolan and Whelan 2011) set the ground for the Europe 2020 agenda for smart, sustainable and inclusive growth. The resulting measure of social exclusion ${ }^{6}$ assesses the lack of some aspects of living conditions, namely housing conditions, possession of durables and capacity to afford basic requirements (Atkinson et al. 2017; Fusco et al. 2013).

In this context, while the Subjective approach and the UBN to multidimensional poverty were mostly applied to developing countries, the social exclusion approach has been formally adopted by European countries, including Italy.

\subsection{The Italian Context}

Indeed, in Italy, official measures of poverty comprise standard monetary indicators (absolute poverty and relative poverty) and measures for social exclusion. The latter goes beyond a purely monetary evaluation of poverty, supplementing monetary poverty indicators with material deprivation and working intensity. However, they do not accommodate a broader multidimensional perspective in which a set of capabilities is assessed (e.g., capability of being healthy, of having social relations, of living an unpolluted environment and so on). Nonetheless, on the side of wellbeing, Italy has made a major effort in recent years to provide a complete framework for measuring Equitable and Sustainable wellbeing, and some indicators of that framework have also been included in the evaluation of fiscal policies by the Ministry of the Economy and Finance (see Ministero dell'Economia e delle Finanze, 2018). The framework was the result of a participatory process in which all groups of civil society and experts were involved in the designing of the dimensions/indicators (see ISTAT 2013-2019). It can thus be considered as a successfully attempt to operationalize the CA (De Rosa 2018). In this context, as far as a broader perspective on multidimensional poverty is

\footnotetext{
5 Nutrition; child mortality; years of schooling; school attendance; cooking fuel; sanitation; drinking water; electricity; housing; asset.

6 The headline indicator for social exclusion is 'people at risk of poverty or social exclusion'. Three subindicators compose it: monetary poverty, severe material deprivation and very low work household intensity.
} 
concerned, Italy has made less effort: only a small number of contributions assessing multidimensional poverty in developed countries include estimates for Italy (Brandolini 2008; Alkire and Apablaza 2016; Alkire et al. 2014). Similarly, few studies have focused on multidimensional poverty in Italy at sub-national level (Billi and Scotti 2018; Coromaldi and Zoli 2012; Betti et al. 2008; Giuliano et al. 2012- see Table 1 for details). Moreover, these contributions ground the choice of their normative framework either within the social exclusion approach or merely relying on the data availability/statistical response, without any specific effort to reconcile the structure of the index with a well-established theoretical framework (see Table 1).

Therefore, this paper seeks to contribute to the literature in two ways: on the theoretical side, it suggests a way to overcome the typical curse of dimensionality by promoting the use of a widely recognized national framework for wellbeing as a normative basis for the construction of the index; on the empirical side, it offers further evidence, with updated and disaggregated figures, on the level and the composition of multidimensional poverty in Italy.

\section{Methodology and the Alkire-Foster Aggregation Method}

Since 2010, the Oxford Poverty and Human Development Initiative (OPHI) has published the Multidimensional Poverty Index, following the Alkire Foster method (AF), and based on three dimensions (Health; Education; Living Standards). ${ }^{7}$ The index embraces a Capabilities perspective and is also suited to adaptation within national and sub-national contexts. ${ }^{8}$ It is currently available for more than one hundred developing countries. The index, and the AF aggregation method, has several strengths, which motivate the choice of the method for this paper. From a theoretical perspective, each step is grounded in the CA (identification of the unit of analysis, selection of the dimensions, indicators and so on) by focusing on poor "individuals" and their inability to fully function, with the claim of capturing the joint deprivations across different life capabilities and their interlinkages. From a technical perspective, the AF method satisfies several criteria: ordinality; dimensional monotonicity; dimensional breakdown; poverty focus. From a practical perspective, the measure uses the counting approach to identify poor individuals and is able to highlight the joint distribution of deprivations. In particular, the MPI is suitable to use for ordinal or binary data and it is particularly attractive for evaluating policy (Alkire et al 2015).

In this context, the identification process follows a dual cut-off strategy and entails several steps (Alkire et al 2015). The first three steps are common to every wellbeing measurement process, while the last steps follow the AF aggregation strategy: (1) Definition of the set of indicators; (2) Identification of the deprivation cutoff (z) for each indicator in order to classify deprived individuals in each area; (3) Selection of

\footnotetext{
7 The indicators are: Child Mortality; Nutrition; Years of schooling; School attendance; Cooking fuel; Toilet; Water; Electricity; Floor; Assets.

8 Examples of official National MPI are found in Mexico, Colombia, Bhutan, and the Philippines. Full list of national MPI reports can be found at: https:/mppn.org/applications/national-measures/
} 


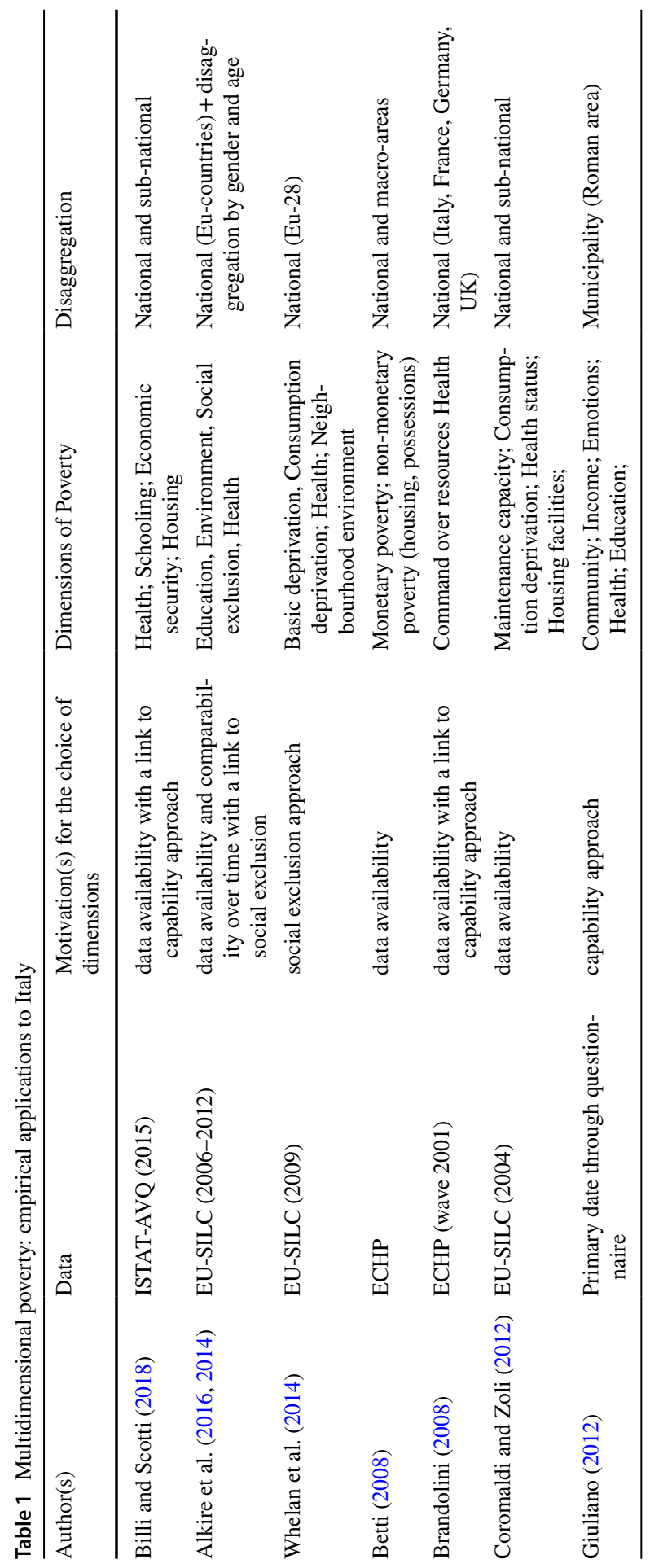


the relative weights (w); (4) Sum of the weighted deprivation for each person, where the deprivation score (c) is given by the weighted sum of individuals' deprivations for each indicator (I) in each dimension (d), $c_{i}=w_{1} I_{1}+w_{2} I_{2}+w_{d} I_{d}$; (5) Determination of the poverty cut-off $(\mathrm{k})$ and identification of the multidimensionally poor, namely those individuals deprived in more than $\mathrm{k}$ dimensions, $\mathrm{c}_{\mathrm{i}} \geq \mathrm{k}$. A key property of the index is the focus on the poor, accomplished by the censoring procedure [censored deprivation score: $\left.\mathrm{c}_{\mathrm{i}}(\mathrm{k})\right]$. The latter refers to the process of considering as not deprived people deprived in some dimensions but not reaching the poverty cut-off (it means that $\mathrm{c}_{\mathrm{i}} \geq \mathrm{k}$ implies $\mathrm{c}_{\mathrm{i}}(\mathrm{k})=\mathrm{c}_{\mathrm{i}} ; \mathrm{c}_{\mathrm{i}}<\mathrm{k}$ implies $\mathrm{c}_{\mathrm{i}}(\mathrm{k})=0$ ), and it allows for the identification of the extent of poverty among those who are multidimensionally poor.

The aggregation process extends the Foster-Greer-Thorbecke (1984) class of poverty measures. Therefore, the MPI (1) is computed as the product of two partial indices: the Headcount Ratio (2) (incidence of poverty $-\mathrm{H}-$ ) and the Intensity of poverty (3) (the breadth $-\mathrm{A}-$ ). Formally':

$$
\begin{gathered}
M_{0}=H \times A \\
H=q / N \\
A=\frac{\sum_{I=1}^{N} C_{i}(k)}{q}
\end{gathered}
$$

with $q$ being the number of multidimensionally poor and $N$ the total population.

Moreover, the index allows subgroups and dimensional decomposition (4) where $h_{d}(k)$ represents the censored headcount for each dimension $D$, as well as the analysis of the changes over time (5) where $X_{t}$ and $X_{t-1}$ is the time operator. ${ }^{10}$

$$
\begin{gathered}
\text { \%contribution_D }=\frac{h_{d}(k) * w_{d}}{M_{0}} \\
\partial M_{0}=\frac{M_{0}\left(X_{t}\right)-M_{0}\left(X_{t-1}\right)}{M_{0}\left(X_{t-1}\right)} * 100
\end{gathered}
$$

\section{The Empirical Application: From the National BES to an MPI for Italy}

As previously recalled, the identification process rests on several assumptions regarding the definition of the normative space of each measure (dimensions/indicators, cutoffs and weights). The Italian BES offers a favourable frame for this normative space.

\footnotetext{
9 Notation follows a synthetic version of Alkire et al. 2011a

10 The formula used to tackle changes over time follows Alkire et al. (2011). Multidimensional poverty index 2011: brief methodological note.
} 
Indeed, in this framework, the design of the dimensions of wellbeing was the result of a participatory process in which experts from universities, the political sphere and civil society were involved in the definition of the indicators. This gave legitimacy to the capabilities identified and reliability to the measurements chosen, making the process less open to accusations of paternalism (De Rosa 2018). The framework currently entails 130 indicators divided in 12 domains (health, education, labour and time balance, economic wellbeing, subjective wellbeing, security, social relations, environment, politics and institutions, research innovation and creativity, quality of services and landscape and cultural heritage) and is used by the Ministry of the Economy and Finance for the evaluation of fiscal policies. In this paper, this nationally recognized framework for wellbeing is used to define the normative space for the construction of the Italian MPI (multidimensional poverty index) and thus proposes a way to overcome the curse of dimensionality by framing multidimensional poverty within the numerous frameworks for wellbeing recently created worldwide. Hence, even though the exercise is tailored to the Italian society, it proposes a method open to replicability within other national contexts or also international frameworks, like the SDGs.

\subsection{Data and Empirical Strategy}

The empirical application uses data from the national household survey "Aspects of daily life" over the decade 2005-2015. The survey, carried out each year since $1993^{11}$ by the Italian National Statistical Institute, collects information on citizen's habits and daily lives in a wide array of areas, with the aim of capturing a general understanding of the national quality of life. The survey is a repeated cross-section and it represents the most important source of information for the BES framework. Around 30\% of the BES indicators directly derive from this survey or can be easily replicated, which is why the paper relies on the BES instead of other surveys. ${ }^{12}$ Hence, the definition of the national MPI is framed in terms of lack of Equitable and Sustainable Wellbeing, where dimensions and indicators are chosen within those of the BES, following four principles: (1) the relevance of the dimension/indicator within the theoretical framework of the BES; (2) the availability of the information in the survey; (3) the comparability of information across time; (4) the empirical robustness. ${ }^{13}$ The resulting multidimensional poverty index embraces 4 dimensions (health, education, economic

\footnotetext{
11 Even though the survey is available since 1993, this analysis starts from 2005 because some relevant measures are available since that year.

12 In particular, an alternative survey could have been EU-SILC, which has also being used for other similar papers (see Table 1). However, the paper relies on "Aspect of daily life" because it is more informative of the BES framework. For instance, the indicator of cultural participation couldn't be used according to Eu-Silc yet it is a constituent indicator of the BES framework. Similarly, other indicators, such as BMI, informatics skills or social participation, which have not been included in this application due to incomparability over time, could eventually be included in further analysis as informing dimension of poverty.

13 The original set of indicators considered was larger. Then association analysis was carried out through Cramer's V and Redundancy $R^{0}$ (Alkire et al. 2015 chapter 7 ) and some indicators were dropped because redundant.
} 
wellbeing, neighbourhood quality) and 12 indicators. Deprivation cut-offs are defined based on metadata available for the BES indicators, explicitly revised to account for poverty. The unit of analysis here is the individual, whereas the unit of identification for most of the indicators computed is the household. The weighting scheme attributes equal weights across dimensions for two reasons: first, a popular way of setting weights is to treat all attributes equally based on the idea that, in the absence of some kind of consensus, each dimension is equally important for human development (Aaberge and Brandolini 2014; Atkinson et al. 2002; Marlier and Atkinson 2010; Nussbaum and Sen 1993); second, the aggregation method used in the BES framework assumes that each sub-dimension is equally important (BES Report 2015 p. 52). Box 1 reports the conceptual framework where the dimensions, BES indicators, deprivation indicators, cut-offs and weights are presented.

Box 1 The normative Framework: domains, indicators, deprivation and weights

\begin{tabular}{|c|c|c|c|c|}
\hline Domains & BES indicators & Deprivation Indicators & Deprivation cut-offs & Weights \\
\hline \multirow[t]{2}{*}{ Health } & $\begin{array}{l}\text { Nutrition: percentage of } \\
\text { persons aged } 3 \text { years } \\
\text { or more that consume } \\
\text { at least } 4 \text { portion of } \\
\text { fruit and/or vegetables } \\
\text { per day over the total } \\
\text { population of } 3 \text { years } \\
\text { or more }\end{array}$ & Nutrition & $\begin{array}{l}\text { Person deprived if } \\
\text { consume less than } 3 \\
\text { portions of fruits or } \\
\text { vegetables per day }\end{array}$ & $1 / 8$ \\
\hline & & Chronic illness & $\begin{array}{l}\text { Person deprived if } \\
\text { suffers from chronic } \\
\text { illness }\end{array}$ & $1 / 8$ \\
\hline \multirow[t]{2}{*}{ Education } & $\begin{array}{l}\text { People with at least } \\
\text { upper secondary } \\
\text { education; People with } \\
\text { tertiary education }\end{array}$ & Education deprivation & $\begin{array}{l}\text { Elementary school not } \\
\text { completed }\end{array}$ & $1 / 8$ \\
\hline & $\begin{array}{l}\text { Cultural participation: } \\
\text { Percentage of people } \\
\text { aged } 6 \text { years and over } \\
\text { who have carried out } \\
3 \text { or more activities } \\
\text { (activities are: going to } \\
\text { the cinema at least four } \\
\text { times, at least once } \\
\text { to the theatre, exhibi- } \\
\text { tions and museums, } \\
\text { archaeological sites, } \\
\text { monuments, concerts } \\
\text { of classical music, } \\
\text { opera, concerts of } \\
\text { other kind of music, } \\
\text { read the newspaper at } \\
\text { least three times per } \\
\text { week, read at least four } \\
\text { books.) }\end{array}$ & Cultural deprivation & $\begin{array}{l}\text { Persons that in the } \\
12 \text { months before the } \\
\text { interview have joined } \\
\text { less than } 3 \text { activities. } \\
\text { The activities consid- } \\
\text { ered are: at least once } \\
\text { to: cinema, theatre, } \\
\text { exhibitions and muse- } \\
\text { ums, archaeological } \\
\text { sites, monuments, } \\
\text { concerts of classical } \\
\text { music, opera, concerts } \\
\text { of other kind of music; } \\
\text { read the newspaper } \\
\text { at least once a week; } \\
\text { read at least one book } \\
\text { in the } 12 \text { months pre- } \\
\text { ceding the interview }\end{array}$ & $1 / 8$ \\
\hline
\end{tabular}




\begin{tabular}{|c|c|c|c|c|}
\hline Domains & BES indicators & Deprivation Indicators & Deprivation cut-offs & Weights \\
\hline \multirow[t]{5}{*}{ Economic wellbeing } & $\begin{array}{l}\text { Severely materially } \\
\text { deprived peo- } \\
\text { ple: Proportion of } \\
\text { people living in } \\
\text { households with } \\
\text { at least } 4 \text { out of } 9 \\
\text { deprivation items }\end{array}$ & Material deprivation* & $\begin{array}{l}\text { Person deprived if } \\
\text { possessing less than } 4 \\
\text { out of } 6 \text { items (items } \\
\text { are: washing machine, } \\
\text { color tv, scooter/moto } \\
\text { or car, phone, personal } \\
\text { computer, can't afford } \\
\text { a holiday) }\end{array}$ & $1 / 20$ \\
\hline & $\begin{array}{l}\text { People suffering poor } \\
\text { housing condi- } \\
\text { tions: Proportion of } \\
\text { people experienc- } \\
\text { ing overcrowding in } \\
\text { houses without some } \\
\text { services and with } \\
\text { structural problems }\end{array}$ & Housing deprivation* & $\begin{array}{l}\text { Person deprived if } \\
\text { experience } 3 \text { or more } \\
\text { deprivations related to } \\
\text { the house (items are: } \\
\text { overcrowding; distance } \\
\text { from basic services } \\
\text { (pharmacy, shops, } \\
\text { school); overall poor } \\
\text { condition of the floors } \\
\text { and/or walls; expenses } \\
\text { too high; house not } \\
\text { owned) }\end{array}$ & $1 / 20$ \\
\hline & $\begin{array}{l}\text { Irregularities in gas } \\
\text { distribution: Percent- } \\
\text { age of households } \\
\text { declaring that the } \\
\text { apartment is supplied } \\
\text { with methane gas out } \\
\text { of total number of } \\
\text { households }\end{array}$ & Gas & $\begin{array}{l}\text { Person deprived if their } \\
\text { house is not served by } \\
\text { methane gas }\end{array}$ & $1 / 20$ \\
\hline & $\begin{array}{l}\text { Irregularities in water } \\
\text { supply: Percentage of } \\
\text { households who report } \\
\text { irregularities in water } \\
\text { supply out of total } \\
\text { number of households }\end{array}$ & Water & $\begin{array}{l}\text { Person deprived if they } \\
\text { declare they have } \\
\text { irregularities in their } \\
\text { water supply }\end{array}$ & $1 / 20$ \\
\hline & People unemployed & Unemployment* & $\begin{array}{l}\text { Person deprived if } \\
\text { unemployed }\end{array}$ & \\
\hline Neighbourhood Quality & $\begin{array}{l}\text { Satisfaction with the } \\
\text { environment: Percent- } \\
\text { age of people aged } \\
14 \text { and over very or } \\
\text { quite satisfied with the } \\
\text { environmental situa- } \\
\text { tion (air, water, noise) } \\
\text { of the area where } \\
\text { they live out of total } \\
\text { population aged } 14 \\
\text { and over }\end{array}$ & $\begin{array}{l}\text { Noise } \\
\text { Crime } \\
\text { Pollution }\end{array}$ & $\begin{array}{l}\text { Persons deprived if the } \\
\text { area in which they live } \\
\text { is declared to be very } \\
\text { noisy; at risk of crime; } \\
\text { polluted }\end{array}$ & $\begin{array}{l}1 / 12 \\
1 / 12 \\
1 / 12\end{array}$ \\
\hline
\end{tabular}

*Indicators for material deprivation, housing and unemployment are built, in the BES original framework, on data coming from EU-Silc survey. Using information from the survey "Aspects of daily life", some proxies have been created. These proxies slightly differ from the original indicators in terms of items considered, yet still capture the underlined phenomenon

The resulting index does not claim to be the only or the most precise measure of poverty for Italy and, as is inherent in multidimensional measurement, the use 
of different surveys, indicators, or aggregation methods could certainly lead to different results. However, it worth remembering that the contribution of the paper is, first, to offer a method for analyzing multidimensional poverty through a well-established framework of wellbeing and, second, to offer updated data on a phenomenon scarcely studied in Italy and one that takes place in a context of rising inequality.

The study concludes with a logistic regression analysis aimed at disentangling the main socio-demographics factors relating to multidimensional poverty.

Formally:

$$
M P I_{i r t}=\alpha+\beta_{\mathrm{j}} I C_{i r t}+\mu_{r}+\lambda_{t}+\varepsilon_{i r t}
$$

where

MPI is a dummy variable assuming value 1 if the individual $i$ in region $r$ at time $t$ is multidimensionally poor, and value 0 otherwise;

IC is the set of socio-demographic characteristics (married, divorced, widow or other forms of marital status, age, gender, household size. Full variables description in "Appendix");

$\boldsymbol{\mu}_{\mathbf{r}}$ and $\boldsymbol{\lambda}_{\mathbf{t}}$ represent respectively region and time fixed effect.

Further analysis checks the robustness of the estimates separately for each of the 12 sub-dimensions of multidimensional poverty (chronic illness, nutrition, schooling, cultural deprivation, crime, noise, pollution, unemployment, water, gas, housing deprivation, material deprivation). Each dependent variable is a dummy variable derived from the censored headcount measure. It assumes a value of 1 if the individual is both multidimensionally poor and deprived in that dimension, and value 0 otherwise.

\section{Results}

As we have seen, the AF adjusted headcount ratio follows a dual cut-offs strategy. Therefore, the deprivation cut-offs were coordinated with the definition of the BES indicators, properly adapted to account for poverty. Conversely, the results describe regional and annual trends for multiple poverty cut-offs (k from 10 to 100\%). In particular, Fig. 1 depicts the adjusted headcount at different cut-offs per year (2005-2015), whereas Fig. 2 depicts the adjusted headcount at different cut-offs per area (North, Centre, South, Islands). As the cut-off increases, the level of the adjusted headcount is reduced, since a higher number of deprivations is required to fall into multidimensional poverty. Thus, for cut-off values higher than $60 \%$, the adjusted headcount approaches zero; it means there are no individuals are jointly poor in more than $60 \%$ of total deprivations. It worth noting that results already show higher MPIs for 2015 and for regions of the South and the Islands.

When the analysis sets a poverty cut-off of $50 \%$, a person must be poor in more than two dimensions or the equivalent sum of weighted deprivations from several dimensions. This decision is based on the popular understandings of "multidimensional" poverty (Alkire and Apablaza 2016). Thus, Fig. 3a-c report the incidence, the intensity and the amount of multidimensional poverty over the years 
by area for a poverty cut-off of $50 \%$. Results for Incidence $\mathrm{H}$ and $\mathrm{M}_{0}$ report a trend line with three peaks, where the first peak is registered in 2006, the second between 2008/2009 and a changing trend from 2013. These figures also show a clear divergence over time between the North/Centre and the South/Islands, with the latter experiencing a dramatic increase in both the incidence and the intensity of poverty. It is worth noting that, overall, multidimensional poverty grew over time with an MPI moving from 0.055 in 2005 to 0.102 in 2015 and the percentage of multidimensionally poor individuals increasing from 9.52 to $17.57 \%$ (Table 2).

Further disaggregation at the regional level is reported in Table 3 and Fig. $4 \mathrm{a}-\mathrm{c}$ where Italian regions are ranked per $\mathrm{M}_{0}, \mathrm{H}$ and $\mathrm{A}$. The gap between Northern/ Central and Southern regions is confirmed with Southern regions placed at the bottom of the rank. However, regions belonging to the Centre and the North are distributed heterogeneously across the ranking. Indeed, Molise is the second-best performing region and Abruzzo, Marche and Basilicata are ranked within the top 6. Conversely Veneto, Lombardia and Lazio are found at the bottom, just a step above Southern regions. In addition, it is worth noting that Abruzzo, Basilicata, and Molise are the only three regions, all from the Centre, to experience, in 2015, a convergence with the national average.

The uncensored headcount reports the proportion of individuals deprived in each indicator, whereas the censored headcount reports those deprived in that indicator and multidimensionally poor. Therefore, the percentage from the first measure is notably larger than the censored percentage. Table 2 reports the results for the uncensored headcount and the censored headcount for each indicator. Here, if we look at individuals defined as multidimensionally poor, we can observe that the percentage of deprived individuals in each dimension has increased over time, with nutrition reporting the largest rise (around 10 percentage points). Overall when looking at the MPI growth rate over the period 2005-2015 (Fig. 5), the largest peaks appear during the years of the crisis, namely in 2008 (growth of more than 40 percent) and in 2013 (growth of more than 50 percent).

Instead, Figs. 6, 7 break down the contributions of each indicator to $\mathrm{M}_{0}$ both over time and across regions. The dimension of health accounts for between 20 and 30 per cent of the total $\mathrm{M}_{0}$ and the trend is increasing, especially due to poor nutrition, since 2013. The education dimension accounts for another 30-35 percent of the index and the effect is mostly due to cultural deprivation, which seems to be the indicator with the higher percentage contribution. The Neighbourhood Quality dimension accounts for almost 30 per cent of the index and the impact of pollution is slightly higher than the impact of crime and noise. The remaining economic dimensions only account for around 10 percent of the index. By contrast, when looking at dimensional composition across regions, it is worth noting that the economic dimension shows a greater contribution in Calabria, Sicily, and Sardinia, whereas the contribution of nutrition deprivation is significantly lower in Campania, Puglia, Basilicata, Calabria and Sicily.

Finally, Table 4 reports logistic regression estimates according to Eq. (6).

The goal of this part of the analysis is to test the probability of addressing multidimensional poverty in consideration of some basic socio-demographic characteristics. As far as the age pattern is concerned, being over 65 years old increases the 

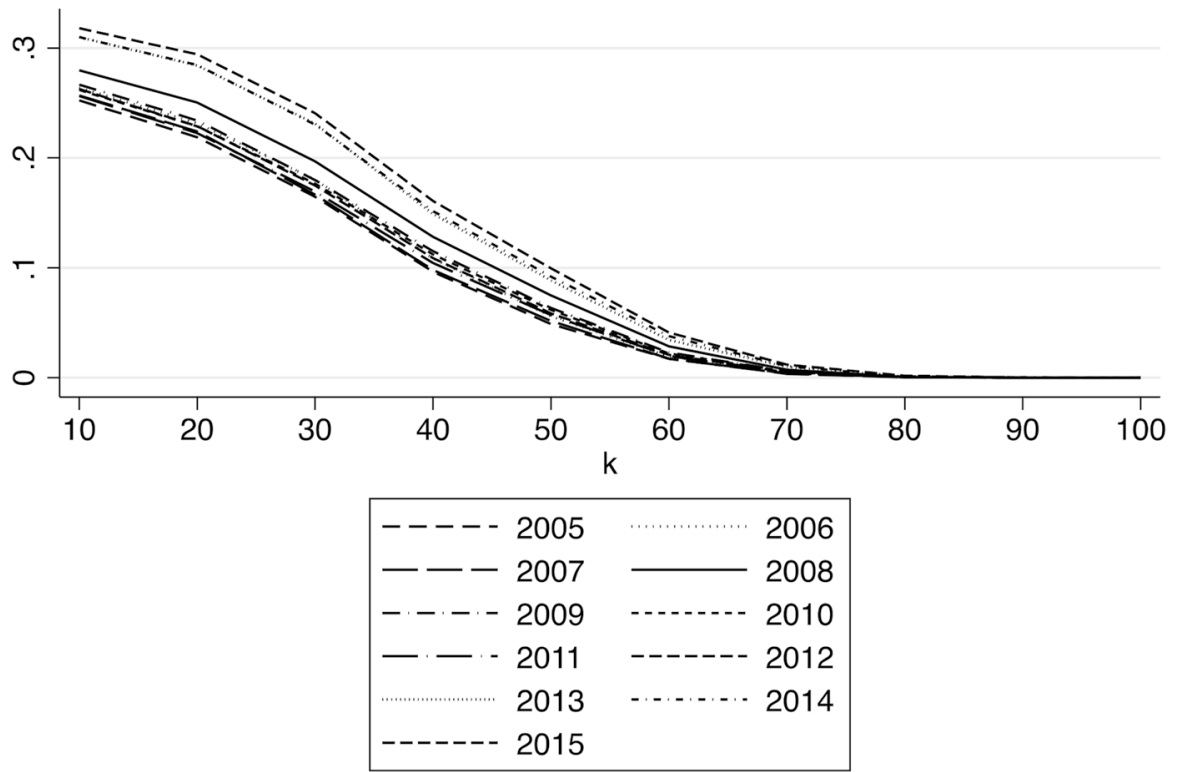

Fig. 1 MPI at different k-level by year

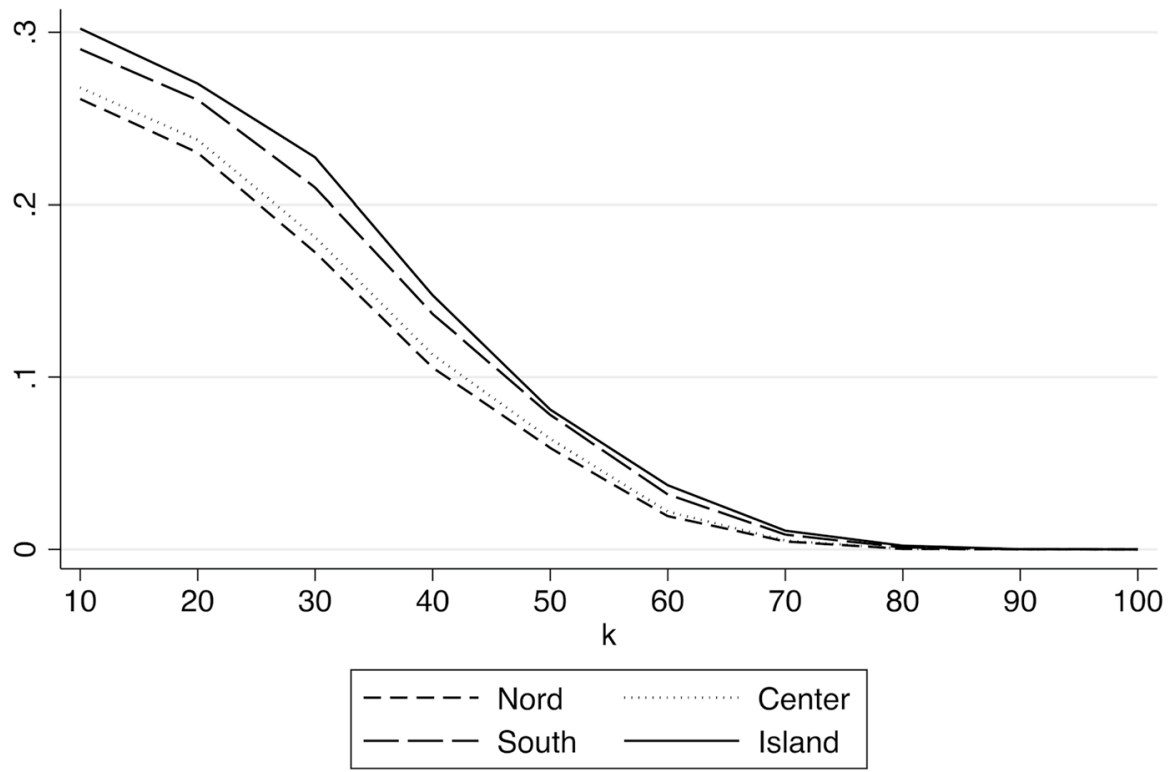

Fig. 2 MPI at different k-level by areas (years' average) 
a Incidence of Poverty over time (H)

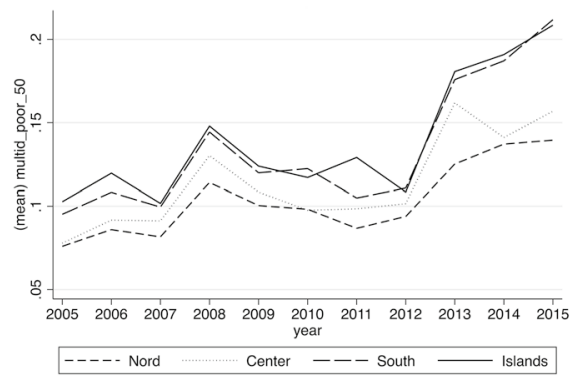

b Intensity of Poverty over time (A)

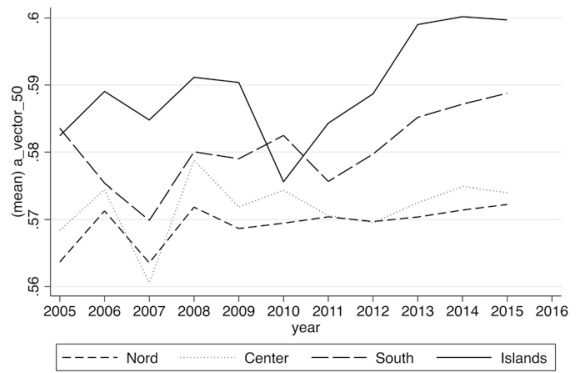

C MPI over time (M0)

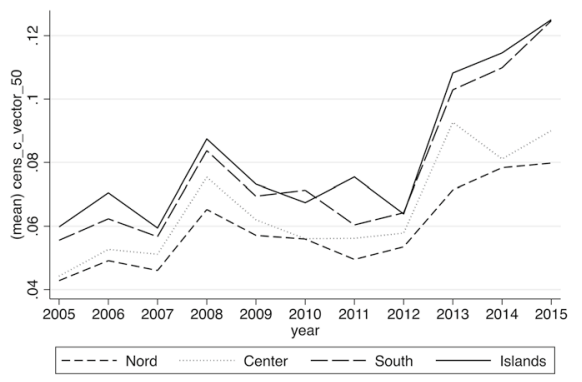

Note: k-level $50 \%$

Fig. 3 a Incidence of Poverty over time $(\mathrm{H})$ b Intensity of Poverty over time (A) c MPI over time (M0). k-level $50 \%$

probability of facing multidimensional poverty: indeed, with respect to the elderly, the youngest persons are $86 \%$ less likely to be poor; those less-younger an $85 \%$ lower probability; those middle-aged a $67 \%$ lower probability. Females are $19 \%$ more likely to become poor than males. Married persons report a $20 \%$ higher probability of becoming poor than single individuals, while divorced/separated individuals have a $7 \%$ higher probability, and the widowed a dramatic $85 \%$ higher probability. Living in a household composed of two to five individuals reduces the probability of experiencing poverty by $10-30 \%$; on the contrary, households with more than five components report a higher probability of being poor than single households. With respect to the region of origin, the reference region is Piedmont. Hence it is worth noting that those living in Campania report a probability of poverty more than twice that of those living in Piedmont. Persons living in Puglia and Sicilia also report a probability of poverty almost twice that of persons in Piedmont. These results remain quite stable across the different sub-dimensions (specification 2-13) both in the sign and the size of the coefficients. However, it is worth highlighting that the trends in the dimension of unemployment go in opposite direction than the overall index for age pattern, gender and household size. This is quite understandable: elderly individuals (65 years and above) are mostly retired and thus not unemployed by definition; also 


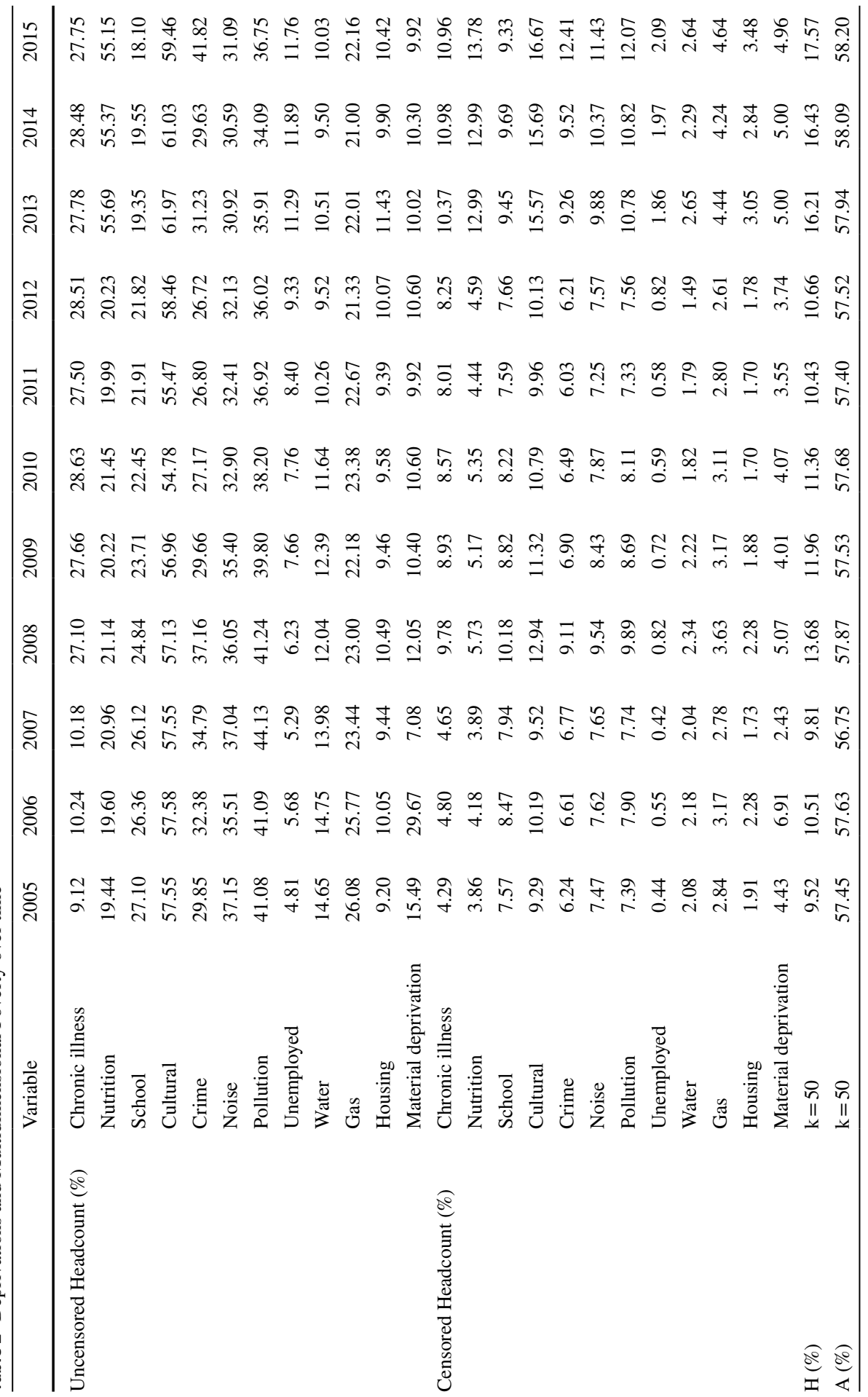




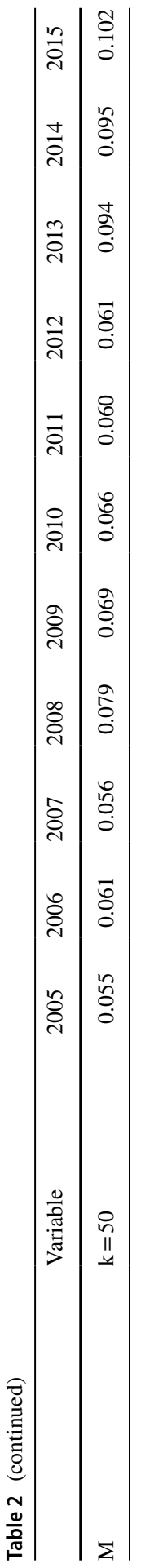


Table 3 Multidimensional poverty by Italian Regions (average years)

\begin{tabular}{|c|c|c|c|}
\hline Region & Rank_H & Rank_A & Rank_M \\
\hline Trentino Alto-Adige & 1 & 3 & 1 \\
\hline Molise & 2 & 4 & 2 \\
\hline Friuli Venezia Giulia & 3 & 1 & 3 \\
\hline Basilicata & 4 & 13 & 4 \\
\hline Abruzzo & 5 & 7 & 5 \\
\hline Marche & 6 & 2 & 6 \\
\hline Liguria & 7 & 8 & 7 \\
\hline Piemonte_-Valle d'Aosta & 8 & 11 & 8 \\
\hline Toscana & 9 & 10 & 9 \\
\hline Umbria & 10 & 5 & 10 \\
\hline Sardinia & 11 & 18 & 12 \\
\hline Emilia Romagna & 12 & 9 & 11 \\
\hline Veneto & 13 & 12 & 13 \\
\hline Lombardia & 14 & 6 & 14 \\
\hline Lazio & 15 & 14 & 15 \\
\hline Calabria & 16 & 16 & 16 \\
\hline Puglia & 17 & 15 & 17 \\
\hline Sicilia & 18 & 19 & 18 \\
\hline Campania & 19 & 17 & 19 \\
\hline
\end{tabular}

\section{a Incidence of poverty over time by Regions (H)}

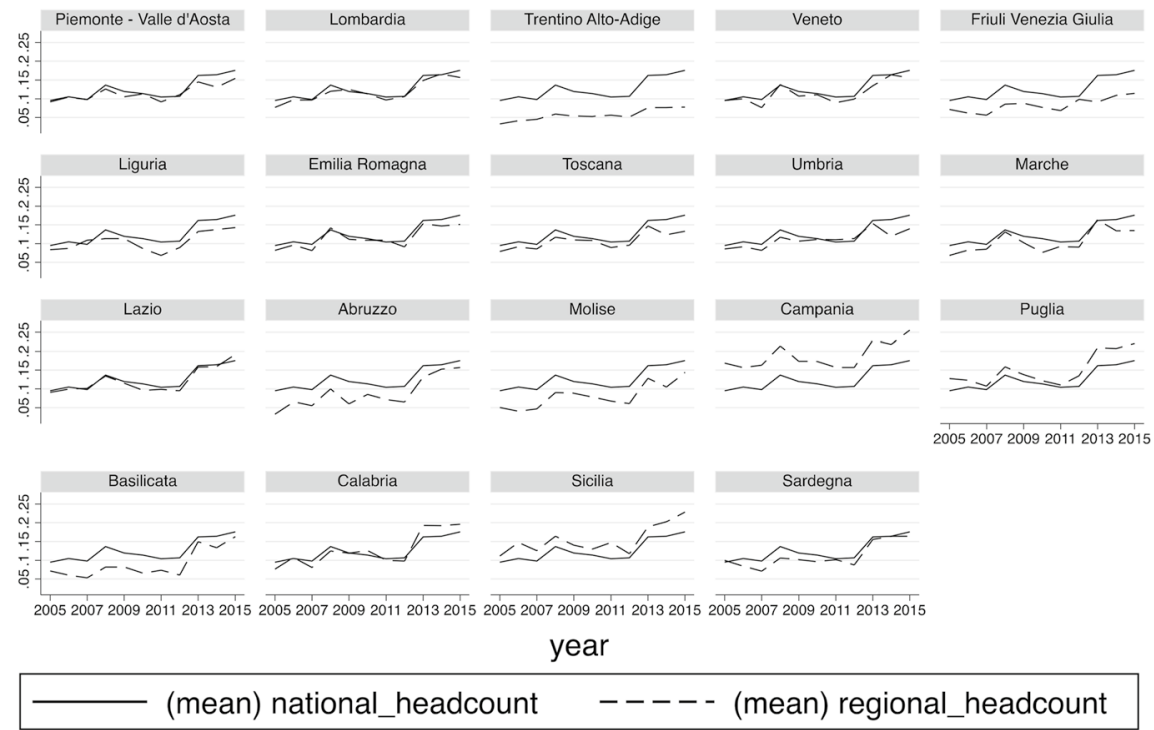

Fig. 4 a Incidence of poverty over time by Regions (H). b Intensity of poverty over time by Regions (A). c MPI over time by Regions 


\section{b Intensity of poverty over time by Regions (A)}

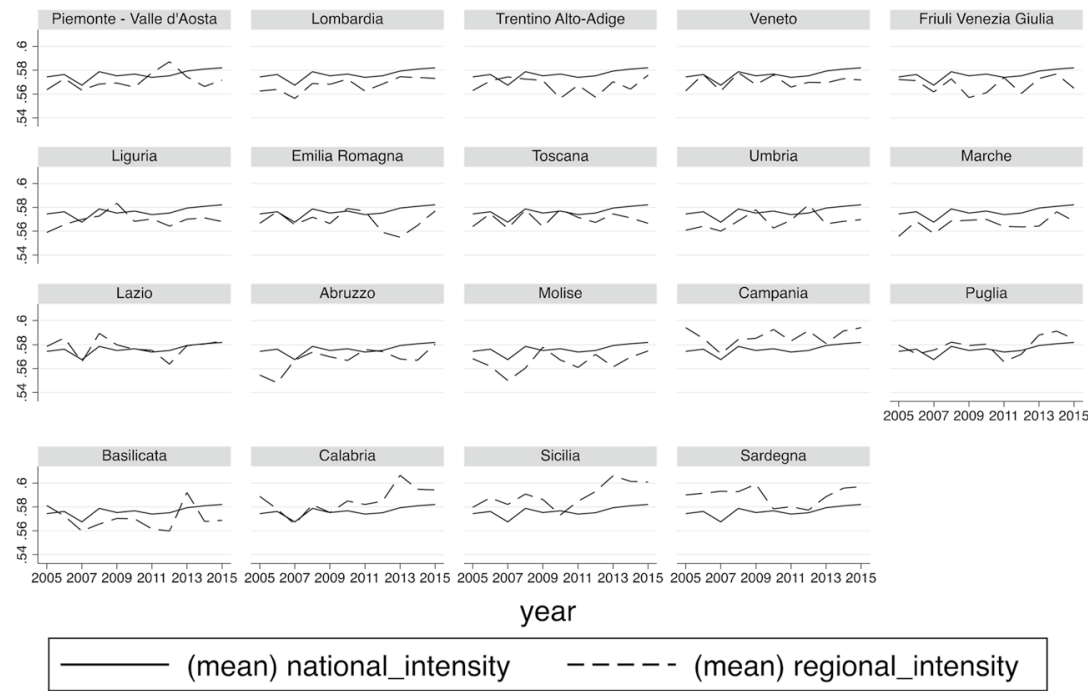

Fig. 4 (continued)

\section{MPI over time by Regions}
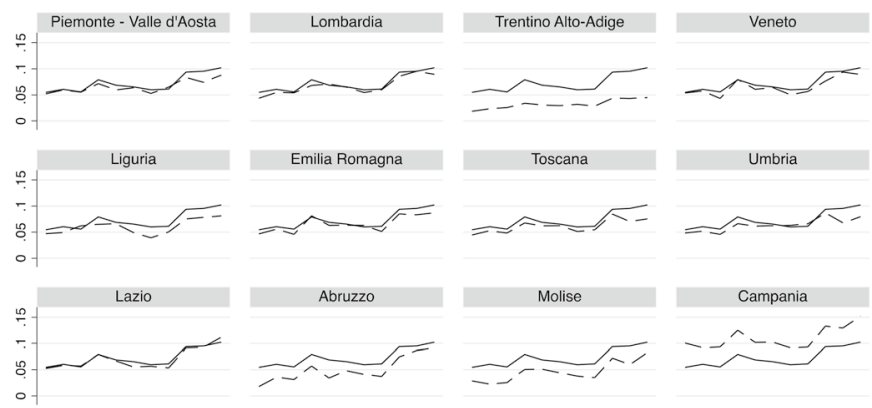

Friuli Venezia Giulia
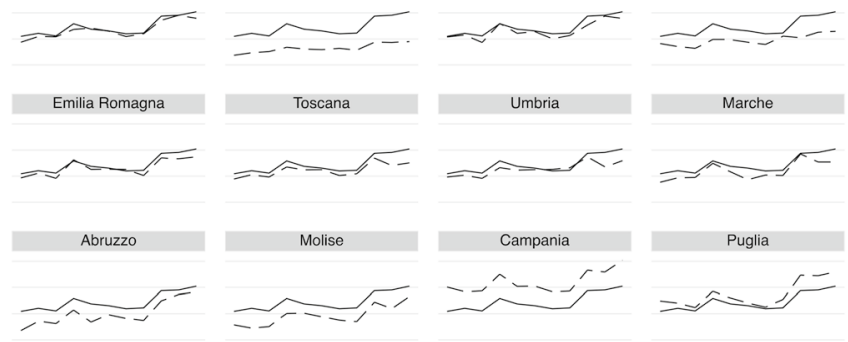

200520072009201120132015
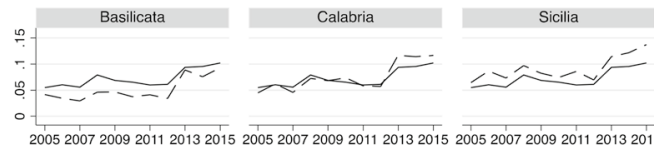

Sardegna

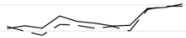

200520072009201120132015200520072009201120132015200520072009201120132015200520072009201120132015

year

_ (mean) national_mpi $\quad-----$ (mean) regional_mpi

Note: k-level 50\%

Fig. 4 (continued) 


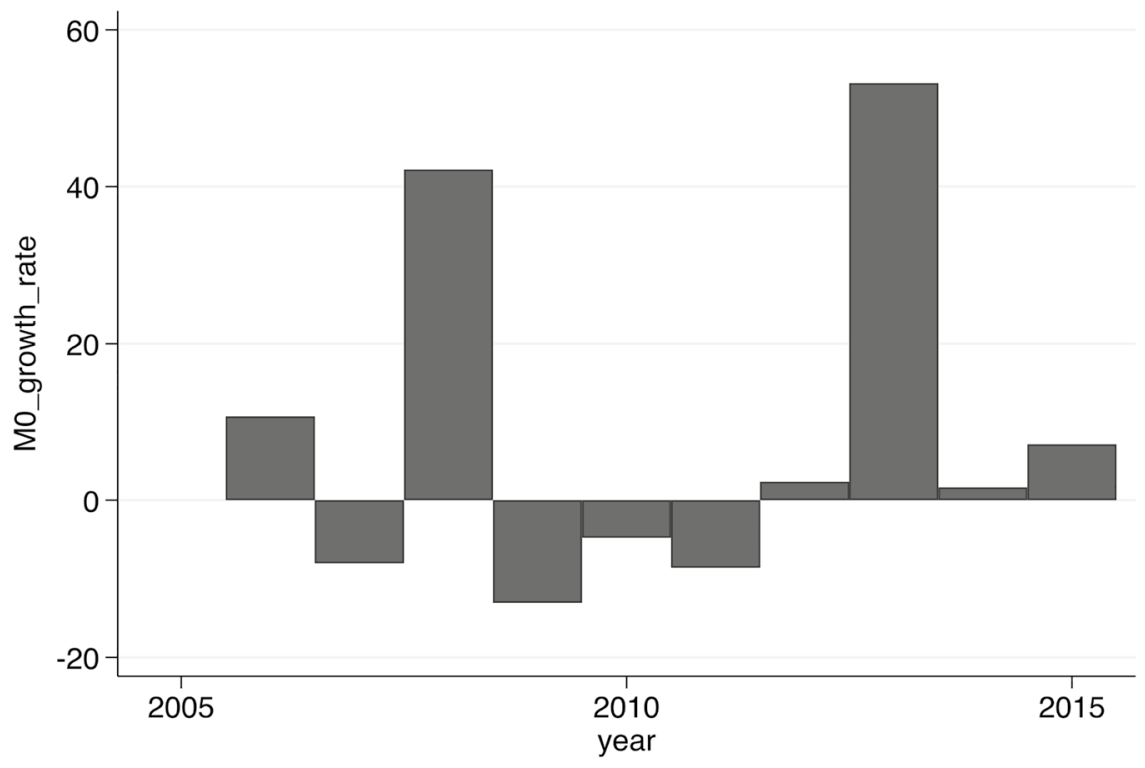

Fig. 5 MPI Relative Rate of Change

females, who are more likely to become poor than males, are also $40 \%$ less likely to be unemployed and multidimensionally poor, mostly due to their lower participation in the labour force.

\section{Conclusions}

The analysis of multidimensional poverty and overlapping deprivations seems particularly urgent in this time of rising inequalities, which has only increased demands to place the most vulnerable groups at the centre of the post-pandemic political agenda. In this context, the paper proposes a multidimensional poverty index for Italy and analyzes the phenomenon at a national and sub-national level over a time span of 10 years.

Key figures highlight that multidimensional poverty has grown over time, with a doubled MPI since 2005 and a percentage of individuals considered as multidimensionally poor increasing from 9.5 percent to 17.5 percent. Nutrition deprivation has risen the most, by around 10 percent, as well as chronic illness, which increased by 6 percent. This suggests that, if the trends to date were continue, individuals deprived in the area of health would be the most vulnerable groups. Not surprisingly, when breaking down the dimensional contributions to multidimensional poverty, the economic dimension accounts only for around 10 percent whereas the other dimensions (Health, Education and Neighbourhood Quality) account each for around 20-30 per cent, confirming widely shared observation that monetary or material deprivation explains only part of the phenomena of poverty. In addition, logistic estimates show 


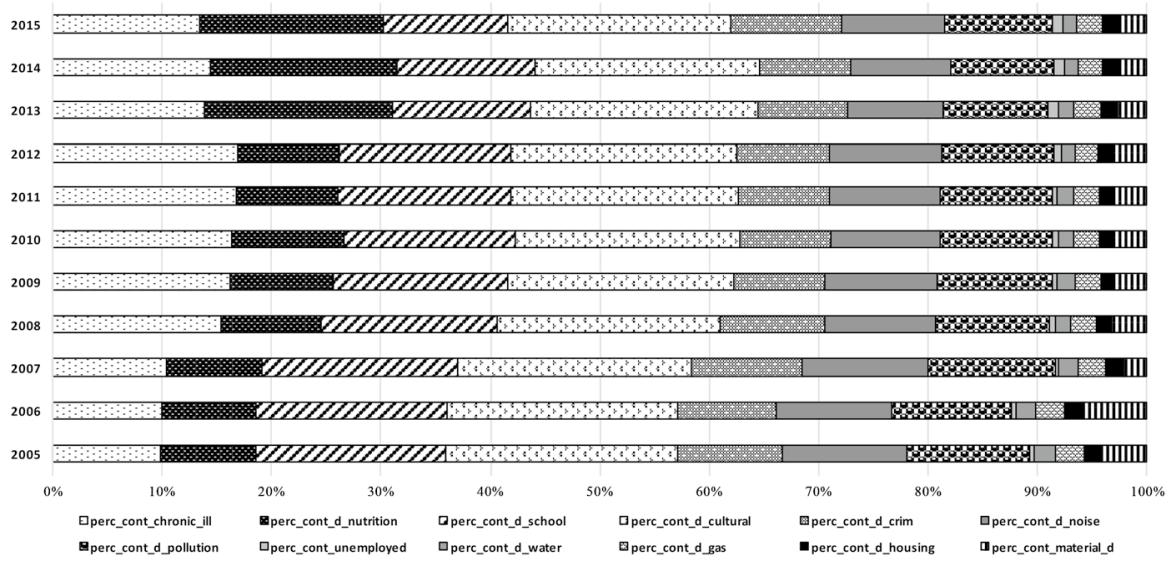

Fig. 6 Dimensional contribution to MPI by years

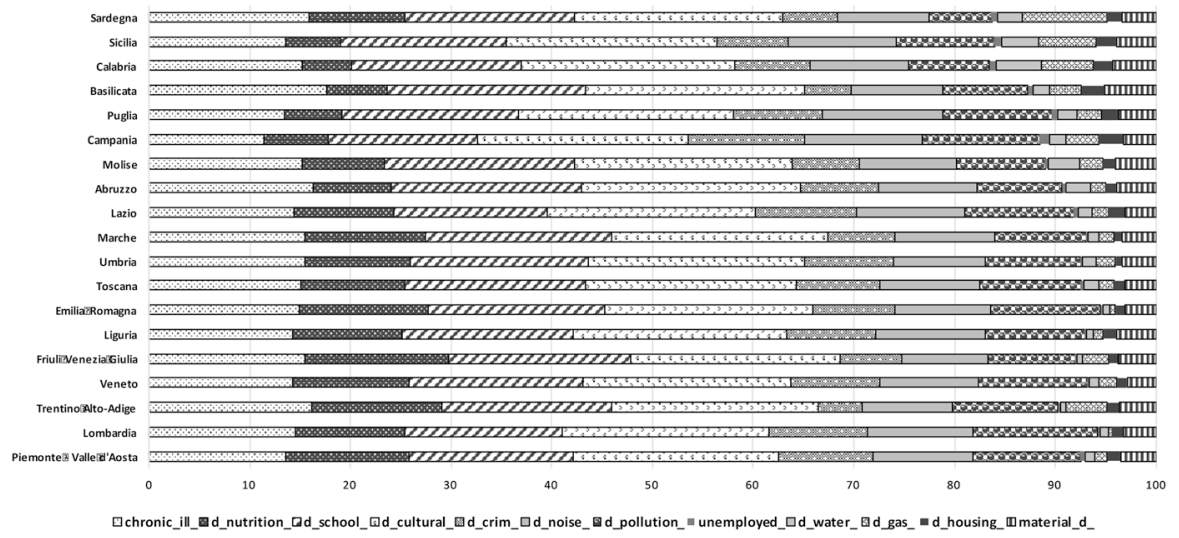

Fig. 7 Dimensional contribution to MPI by Regions

some interesting results: being older, widowed or living alone or in a household composed of more than five individuals increases the probability of poverty. Indeed, these groups have been among the most impacted by the pandemic.

Even though the analysis and the results may change if different surveys, indicators, or aggregation methods were applied, the work is innovative in two ways. First, it presents a novel method that normatively grounds multidimensional poverty within the well-established national framework for wellbeing (BES), proposing a way of setting dimensions/indicators able to be replicated within other national contexts, perhaps even applying international framework like the SDGs. Second, it offers an updated and disaggregated picture of the level and the composition of multidimensional poverty in Italy at the time just before the pandemic.

Further work is needed. In particular, the analysis was aimed at investigating multidimensional poverty not only across regions but especially over time, therefore 


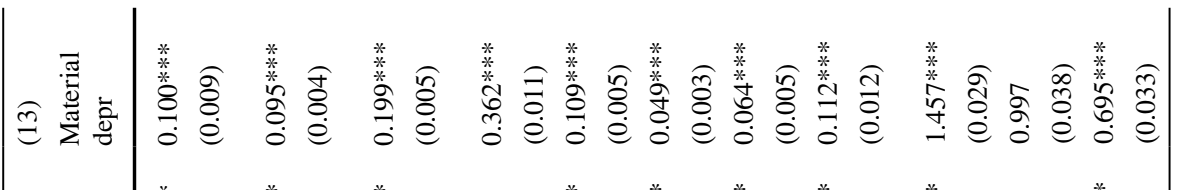

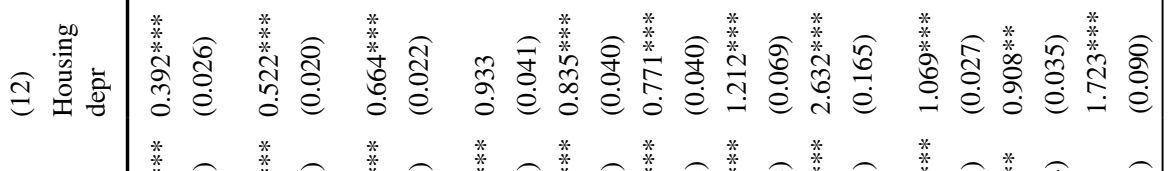

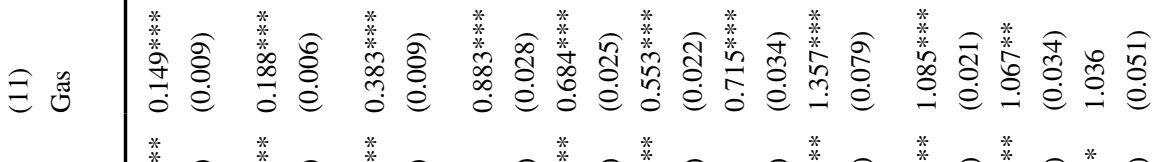

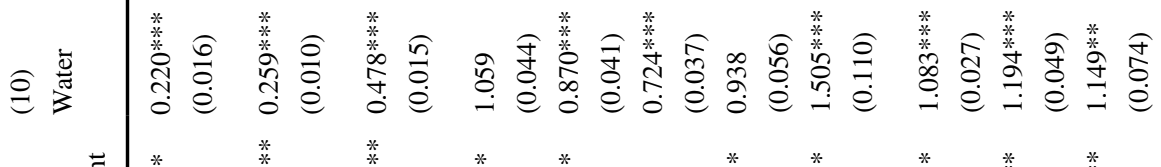

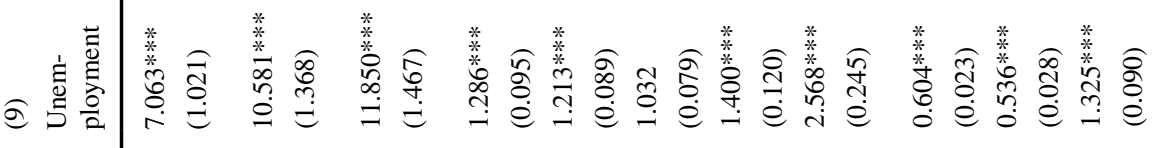

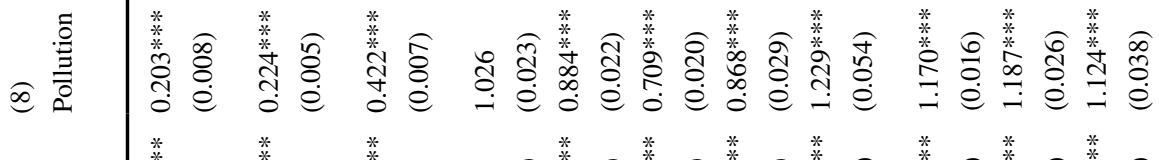

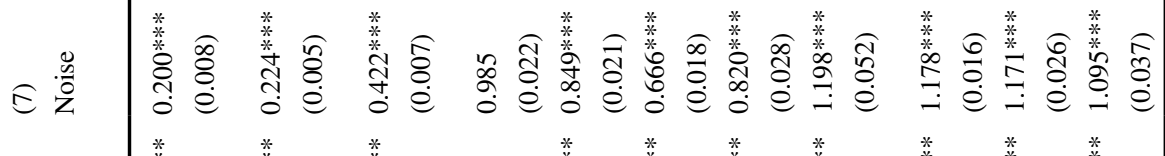

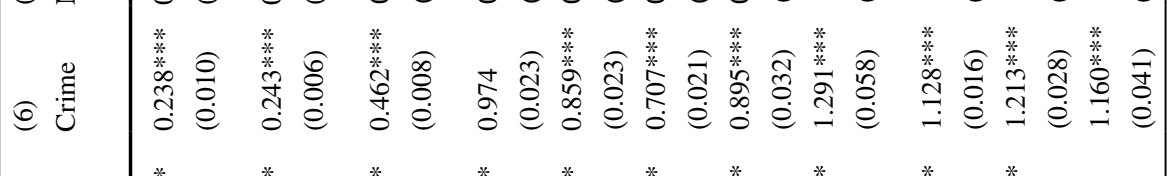

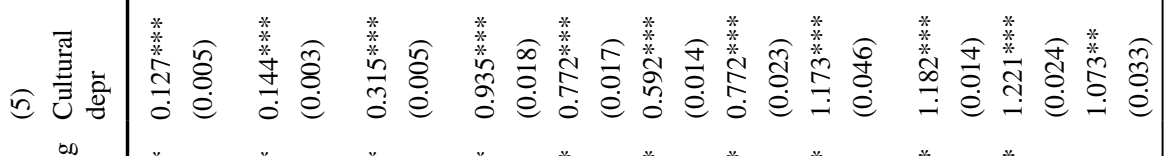
范

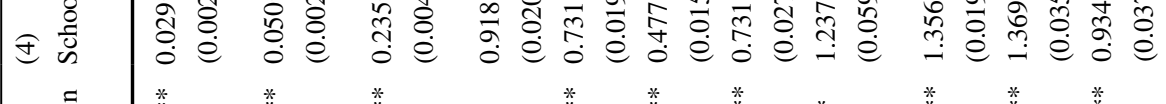

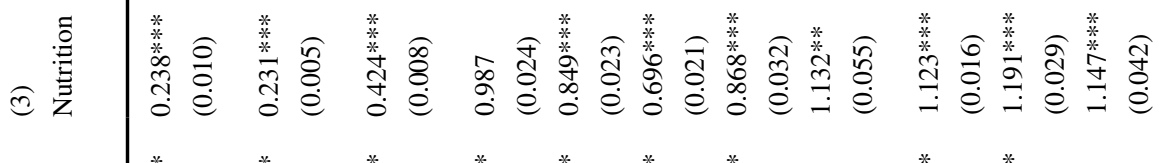

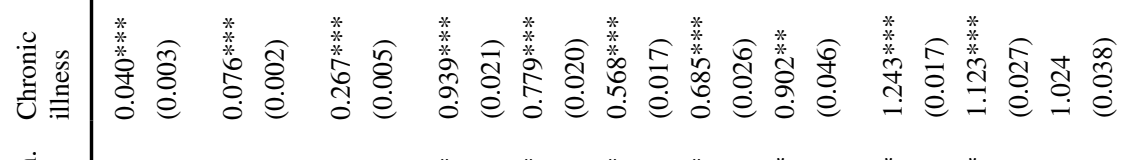

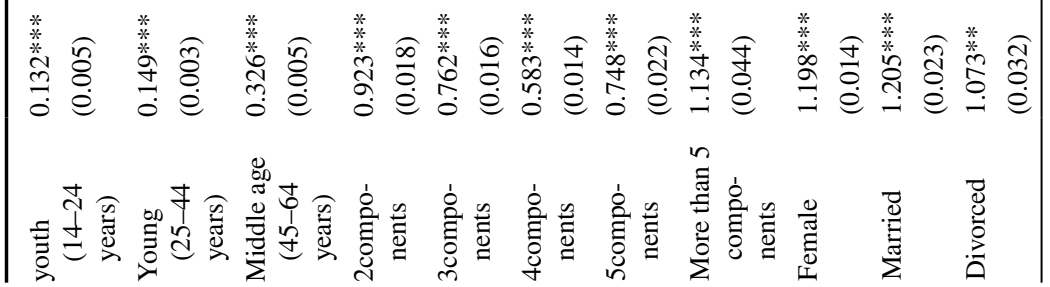




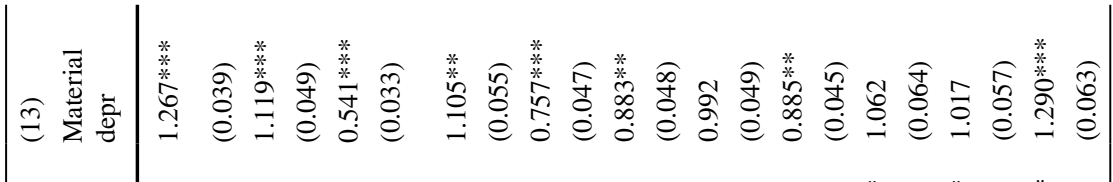

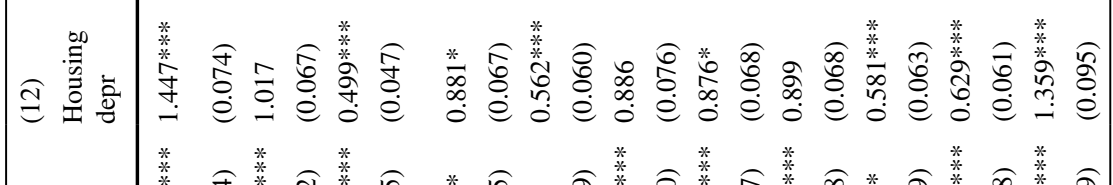

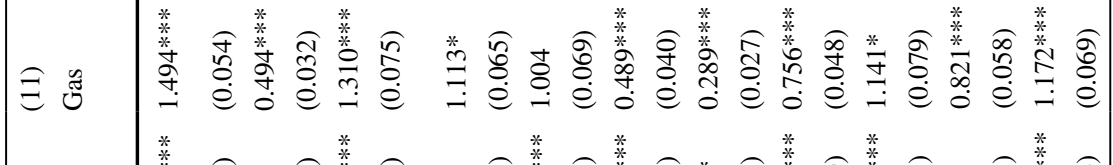

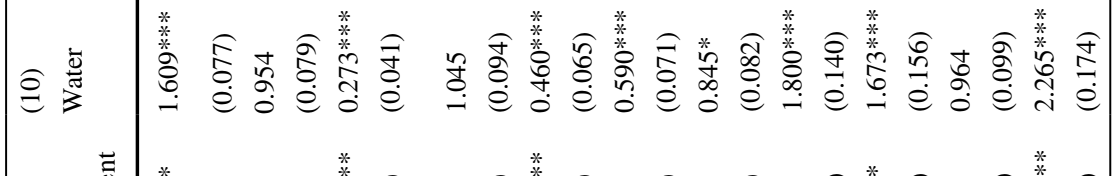

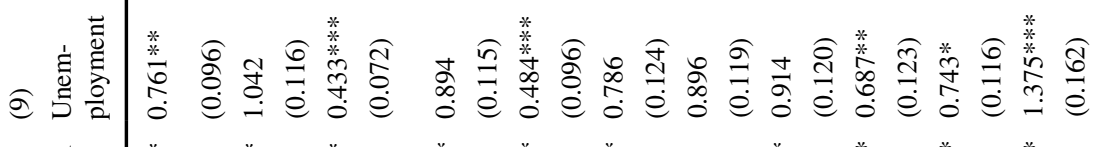

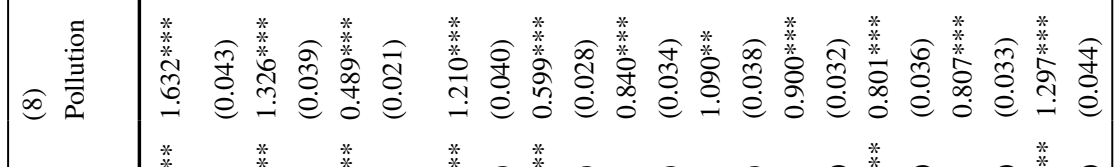

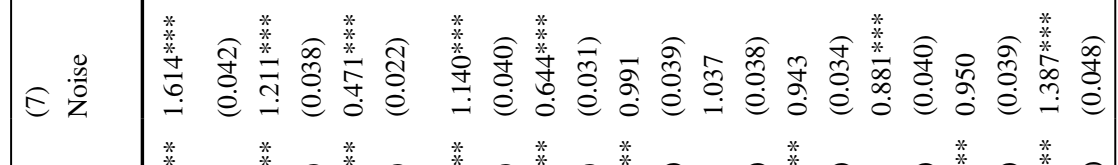

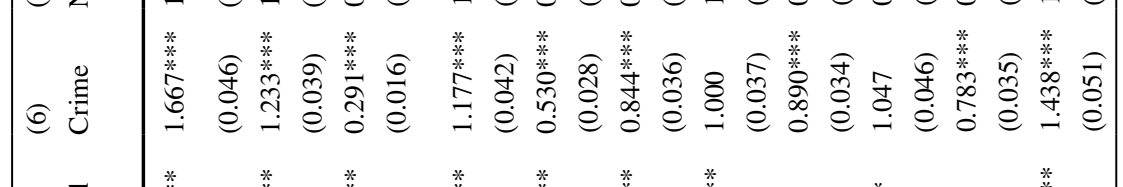

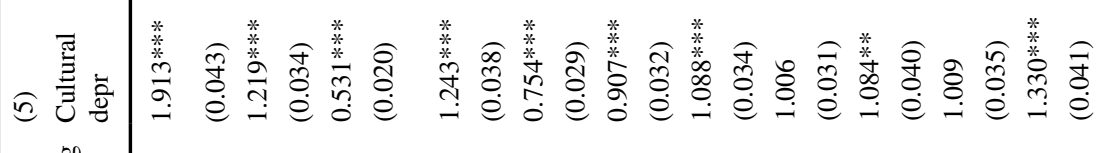

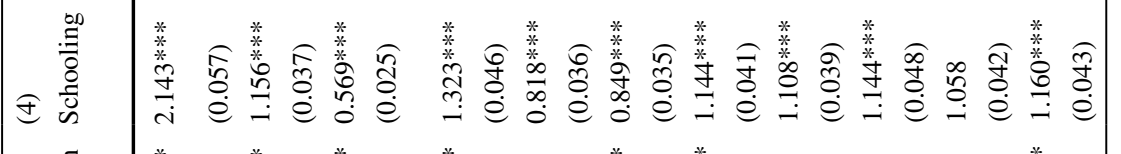

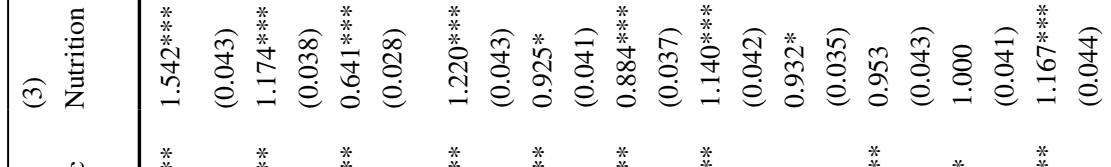

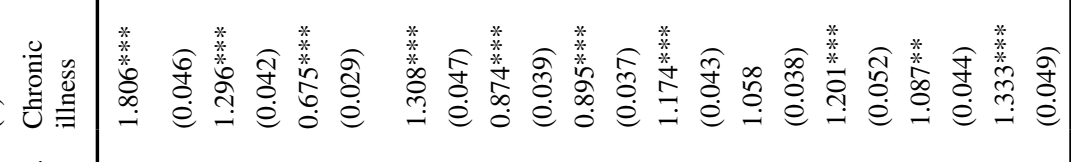

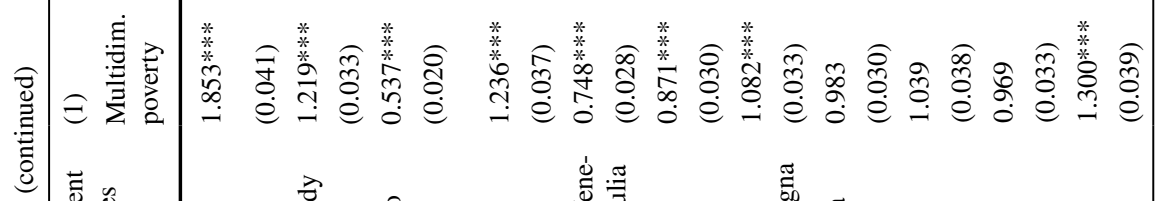

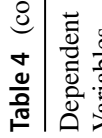
$\mid \frac{2}{3}$

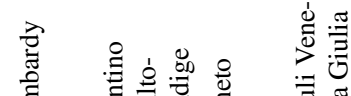

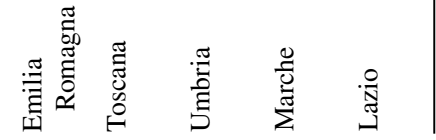




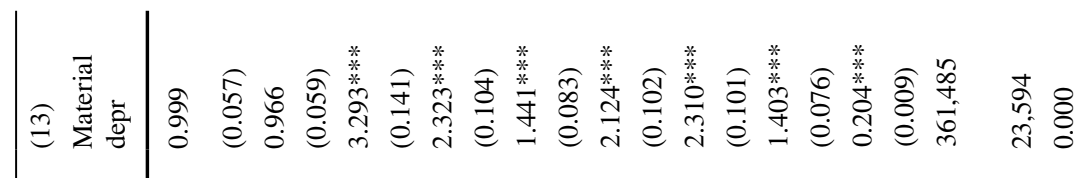

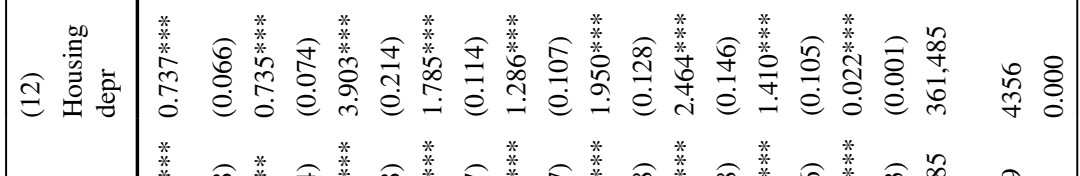

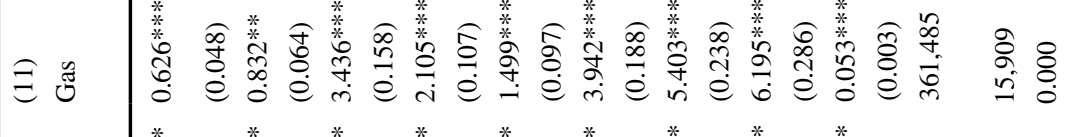

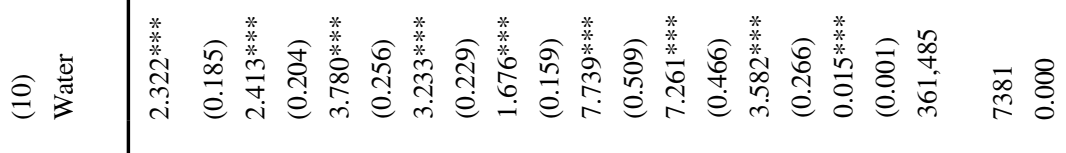

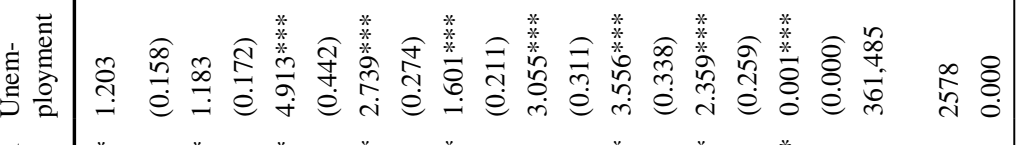

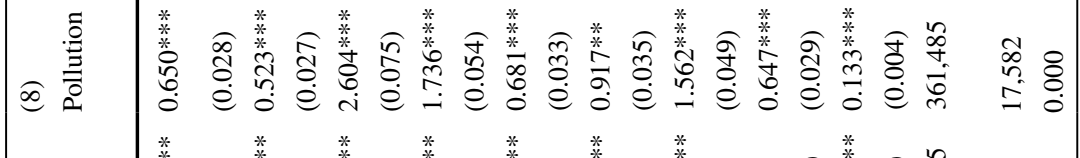

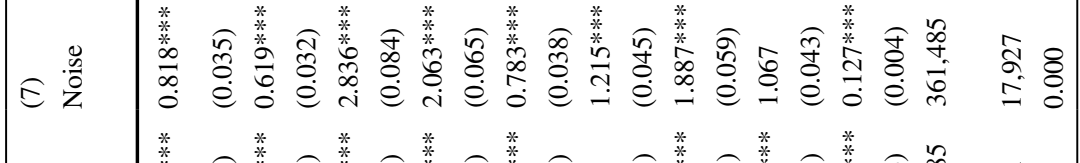

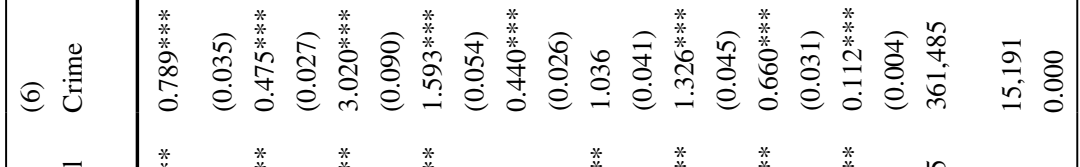

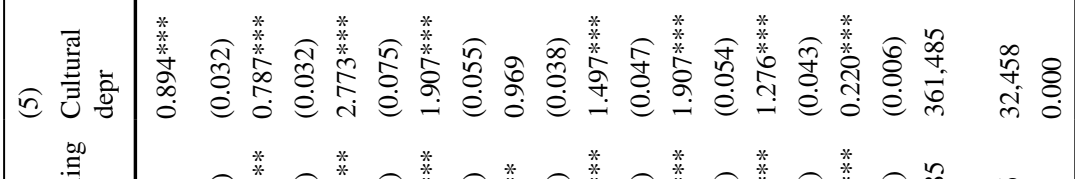

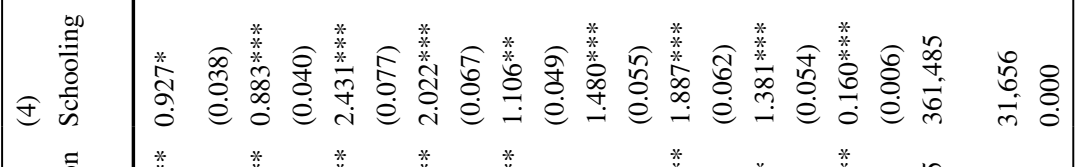

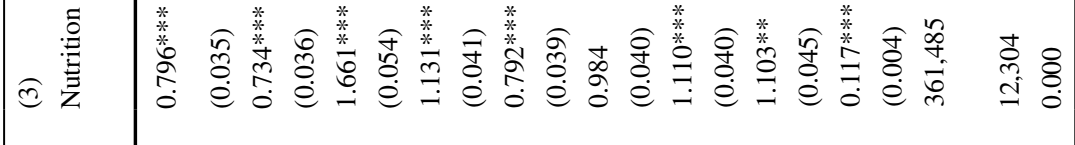

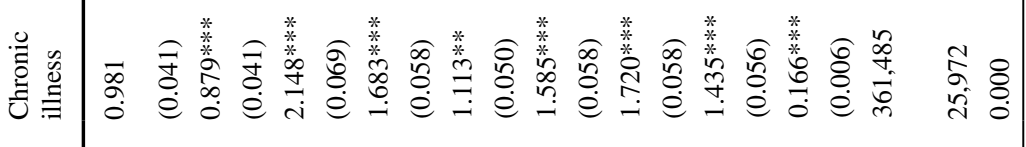

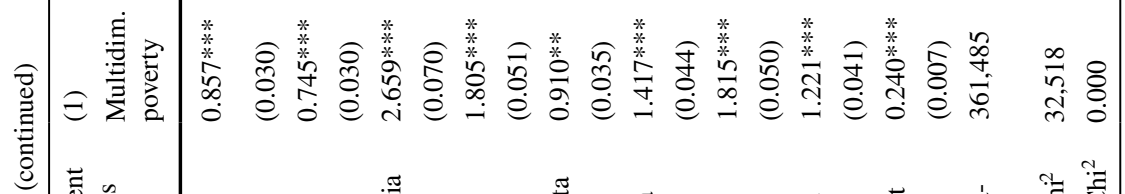

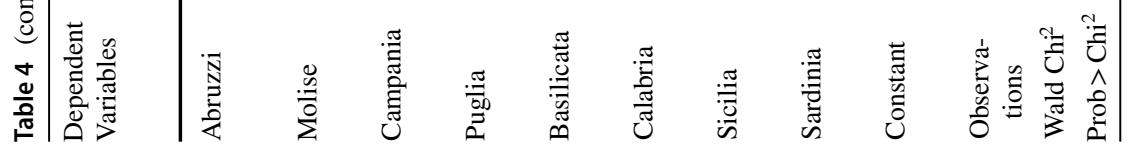




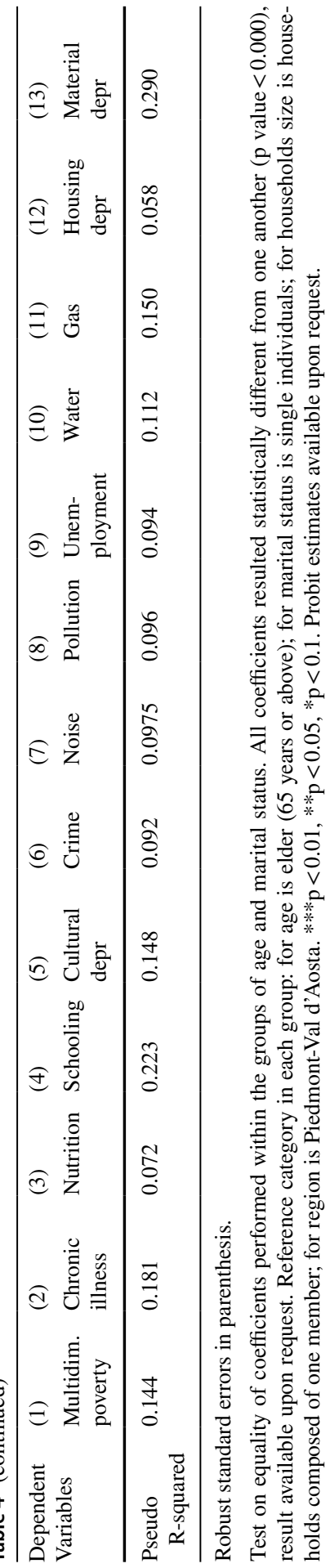


some important indicators or dimensions present in the BES framework (e.g., obesity and BMI, computer skills, social participation, satisfaction with certain life domains) were not included in the analysis due to the impossibility of harmonizing these variables over several years. Hence, further research including these important dimensions for multidimensional poverty could be beneficial, especially if the scope were to include an inequalities analysis. Moreover, logistic estimates were aimed at isolating a basic poverty profile, yet the lack of proper panel data hampered a deeper analysis of the dynamics of transitions to or from poverty, which could be valuable for better identifying vulnerable groups.

\section{Appendix}

See Tables 5, 6 .

Table 5 Variables description

\begin{tabular}{ll}
\hline Age class & $\begin{array}{l}\text { Youth }=14-24 \text { years; young }=25-44 \text { years; } \\
\text { middle age }=45-64 \text { years; } \text { elder }=65 \text { and } \\
\text { over }\end{array}$ \\
\hline Gender & $\begin{array}{l}\text { Female }=1 ; \text { male }=0 \\
\text { Marital status }\end{array}$ \\
Single individual; married; divorced; widow \\
Regionold size & $\begin{array}{l}\text { Number of components living in the house } \\
\text { List of Italian regions }\end{array}$ \\
\hline
\end{tabular}




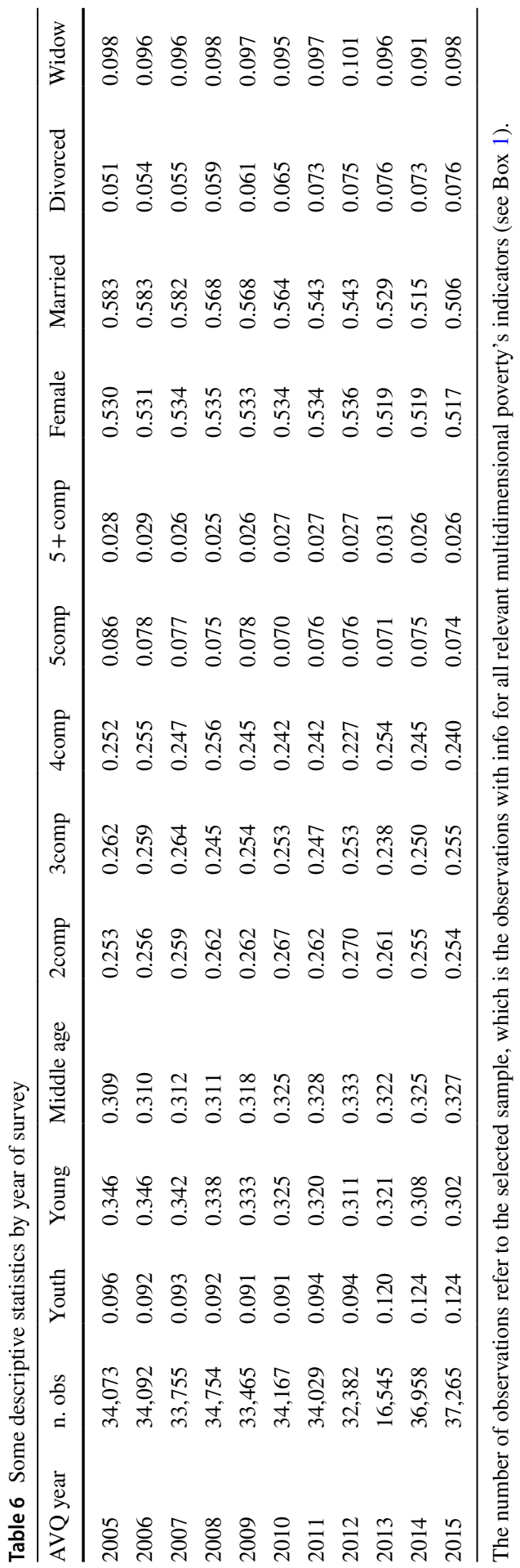


Acknowledgements This project is started after the Oxford Poverty and Human Development Initiative's Summer School 2017 in Marrakesh. Therefore, I would like to acknowledge the OPHI team for priceless instructions and all the participants for valuable discussions. I am also grateful to LUMSA University and the Members of the PhD in Civil Economy for having supported me. The responsibility for the results reported in this paper and their interpretation is entirely my own.

\section{References}

Aaberge R, Brandolini A (2014) Multidimensional poverty and inequality

Alkire S (2002) Dimensions of human development. World Dev 30(2):181-205

Alkire S, Apablaza M (2016) "Multidimensional poverty in Europe 2006-2012: Illustrating a methodology." OPHI Working Paper 74, University of Oxford.

Alkire S, Klasen S (2013) The Multidimensional poverty index (MPI) and monetary poverty: dynamic comparisons from 12 country studies. Mimeo

Alkire S, Roche JM, Santos ME, Seth S (2011) 'Multidimensional Poverty Index 2011: Brief Methodological Note'. OPHI Briefing 07

Alkire S, Foster J, Santos ME (2011b) Where did identification go. J Econ Inequality 9(3):501-505

Alkire S, Apablaza M, Jung E (2014) 'Multidimensional poverty measurement for EUSILC countries.' OPHI Research in Progress 36b

Alkire S, Foster JE, Seth S, Santos ME, Roche JM, Ballon P (2015) Multidimensional poverty measurement and analysis. Oxford University Press, Oxford

Alkire S, Dirksen J, Nogales R, Oldiges C (2020) 'Multidimensional poverty and COVID-19 risk factors: A rapid overview of inter- linked deprivations across 5.7 billion people', OPHI Briefing 53, Oxford Poverty and Human Development Initiative, University of Oxford

Atkinson AB (2017) Monitoring global poverty: report of the commission on global poverty. World Bank, Washington

Atkinson T, Cantillon B, Marlier E, Nolan B (2002) Social indicators: the EU and social inclusion. Oxford University Press, Oxford

Atkinson AB, Guio AC, Marlier E (eds) (2017) Monitoring social inclusion in Europe. Publications Office of the European Union, Luxembourg

Bacchini F, Benedetti I, Laureti T (2019) Makswell: An EU project on MAKing Spatialand temporal multivariate analysis of WELL-being: an application to the Italian equitable and sustainable WELL-being. Technical report, Paper presented at ISI World Statistics Congresses

Bacchini F, Baldazzi B, Di Biagio L (2020) The evolution of composite indices of well-being: an application to Italy. Ecol Indicators 117:106603

Bandura R (2008) A survey of composite indices measuring country performance: 2008 update. New York: United Nations Development Programme, Office of Development Studies (UNDP/ODS Working Paper)

Betti G, Cheli B, Lemmi A, Verma V (2008) The fuzzy set approach to multidimensional poverty: the case of Italy in the 1990s. In Quantitative approaches to multidimensional poverty measurement (pp. 30-48). Palgrave Macmillan, London

Billi A, Scotti M (2018). ultidimensional poverty measures: lessons from the application of the MPI in Italy. In International Symposium on New Metropolitan Perspectives (pp. 652-660). Springer, Cham

Boltvinik J (1999) Poverty measurement methods: an overview (pp. 57-83). UNDP Social Development \& Poverty Elimination Division

Bourguignon F (2006) From income to endowments: the difficult task of expanding the income poverty paradigm. Poverty Inequality, 76-102

Bourguignon F, Chakravarty SR (2003) The measurement of multidimensional poverty. J Econ Inequality $1: 25-49$

Bourguignon F, Bénassy-Quéré A, Dercon S, Estache A, Gunning JW, Kanbur R et al. (2010) The millennium development goals: an assessment. Equity and growth in a globalizing world, 17

Brandolini A (2008) On applying synthetic indices of multidimensional wellbeing: health and income inequalities in selected EU countries 
Burchi F, Gnesi C (2016) A review of the literature on wellbeing in Italy: a human development perspective. In Forum for Social Economics (Vol. 45(2-3): pp. 170-192). Routledge

Burchi F, P De Muro, Kollar E (2014) Which dimensions should matter for capabilities? A constitutional approach. J Ethics Social Welfare 8

Burchi F, Rippin N, Montenegro CE (2020) The measurement of multidimensional poverty across countries: a proposal for selecting dimensions. In Dimensions of Poverty (pp. 281-300). Springer, Cham

Callan T, Nolan B, Whelan CT (1993) Resources, deprivation and the measurement of poverty. J Soc Policy 22(2):141-172

Coe R, Weidmann B, Coleman R, Kay J (2020) Impact of school closures on the attainment gap: rapid evidence assessment. 2020

Coromaldi M, Zoli M (2012) Deriving multidimensional poverty indicators: methodological issues and an empirical analysis for Italy. Soc Indic Res 107(1):37-54

De Rosa D (2018) Capability approach and multidimensional well-being: the Italian case of BES. Soc Indic Res 140(1):125-155

Drèze J, Sen A (2013) An uncertain glory: India and its contradictions. Princeton University Press

Feres JC, Mancero X (2001) El método de las necesidades básicas insatisfechas (NBI) y sus aplicaciones a América Latina, Series Estudios Estadísticos y Prospectivos. Santiago, Chile: CEPAL

Foster J, Greer J, Thorbecke E (1984) A class of decomposable poverty measures. Econometrica: J Econ Soc 761-766

Fusco A, Guio AC, Marlier E (2013) Building a material deprivation index in a multinational context: lessons from the EU experience. In Poverty and social exclusion around the Mediterranean Sea (pp. 43-71). Springer, Boston

Giuliano GA, Raciti P, Tenaglia S, D'Emilione M, Fabrizi L e Vivaldi VP (2012) Gli utenti dei servizi sociali nello spazio delle capabilities: una applicazione del Modello MACaD. Roma: Isfol Occasional Paper, numero 4

Glassman B (2019) Multidimensional deprivation in the United States: 2017. US Census Bureau, Washington

ISTAT, Rapporto Bes: II benessere equo e sostenibile in Italia. 2013, 2014, 2015, 2016, 2017, 2018, 2019

Kalsen S (2000) Measuring poverty and deprivation in South Africa. Rev Income Wealth 46:33-58

Mack J, Lansley S (1985) Poor Britain. Allen and Unwin, London

Marlier E, Atkinson AB (2010) Indicators of poverty and social exclusion in a global context. J Policy Anal Manage 29:285-304

Muffels R, Vrien M (1991) The comparison of definitions of consumption deprivation and income deprivation. Tilburg University, Mimeo

Naraya D, Patel R, Schafft K, Rademacher A, Koch-Schulte S (2000a) Can anyone hear us? Voices of the poor. The World Bank

Narayan D, Chambers R, Shah MK, Petesch P (2000) Voices of the poor: crying out for change. Oxford University Press for the World Bank, New York

Nolan B, Whelan CT (2011) Poverty and deprivation in Europe for a review of empirical studies across Europe

Nussbaum M, Sen A (Eds.) (1993) The quality of life. Oxford University Press

Ringen S (1988) Direct and indirect measures of poverty. J Soc Policy 17(3):351-365

Sen AK (1983) Poor, relatively speaking. Oxford Economic Papers, No. 37, pp. 669-76, Reproduced in Sen AK 1984, pp. 325-345

Sen A (2004) Capabilities, lists, and public reason: Continuing the conversation. Feminist Econ 10(3):77-80

Stiglitz JE, Sen A, Fitoussi JP (2009) Report by the commission on the measurement of economic performance and social progress

Streeten P, Burki SJ, Haq U, Hicks N, Stewart F (1981) First things first: meeting basic human needs in the developing countries

Suppa N (2018) Towards a multidimensional poverty index for Germany. Empirica 45(4):655-683

Tavares FF, Betti G (2021) The pandemic of poverty, vulnerability, and COVID-19: Evidence from a fuzzy multidimensional analysis of deprivations in Brazil. World Dev 139:105307

Townsend P (1979) Poverty in the United Kingdom: a survey of household resources and standards of living. Univ of California Press

Whelan CT, Layte R, Maitre B, Nolan B (2001) Income, deprivation, and economic strain. An analysis of the European community household panel. Eur Sociol Rev 17(4):357-372 
Whelan CT, Layte R, Maître B (2004) Understanding the mismatch between income poverty and deprivation: a dynamic comparative analysis. Eur Sociol Rev 20(4):287-302

Whelan CT, Nolan B, Maitre B (2014) Multidimensional poverty measurement in Europe: an application of the adjusted headcount approach. J Eur Soc Policy 24(2):183-219

WHO (2018) Household air pollution and health (World Health Organization Fact sheets) Retrieved April, 2020, from https://www.who.int/news-room/fact-sheets/detail/household-air-pollution-and-health/

WHO (2020a) Coronavirus disease (COVID-19) advice for the public. Retrieved May 26, 2020, from https:// www.who.int/emergencies/diseases/novel-coronavirus-2019/advice-for-public/

WHO (2020b) Water, sanitation, hygiene, and waste management for the COVID- 19 virus. World Health Organization, WHO reference number: WHO/2019- nCoV/IPC_WASH/2020.3. Retrieved May, 2020, from https://www.who.int/publications-detail/water-sanitation-hygiene-and-waste-management-for-thecovid-19-virus-interim-guidance/

Publisher's Note Springer Nature remains neutral with regard to jurisdictional claims in published maps and institutional affiliations. 